\title{
INFLUENCE OF GRAZING INTENSITY ON SWAMP PLANT COMMUNITIES IN THE TROPICAL MONTANE WETLAND ECOSYSTEMS, NILGIRIS, SOUTHERN INDIA
}

\author{
MOHANDASS, D. ${ }^{*}$-CAMPBELL, M. J. ${ }^{2}-$ BENG, K. C. ${ }^{3}$ - DAVIDAR, P. ${ }^{4}$ \\ ${ }^{1}$ Key Laboratory of Tropical Forest Ecology, Xishuangbanna Tropical Botanical Garden \\ (XTBG), Chinese Academy of Sciences (CAS), \\ Menglun, Mengla County, Yunnan 666 303, P. R. China \\ ${ }^{2}$ Centre for Tropical Environmental and Sustainability Science (T.E.S.S), College of Science \\ and Engineering, James Cook University, \\ Cairns, Queensland, Australia \\ ${ }^{3}$ Center for Integrative Conservation, Xishuangbanna Tropical Botanical Garden (XTBG), \\ Chinese Academy of Sciences (CAS), Menglun, Mengla, \\ Yunnan 666 303, P.R. China \\ ${ }^{4}$ Department of Ecology and Environmental Sciences, Pondicherry University, Kalapet, \\ Puducherry 605 014, India \\ *Corresponding author \\ e-mail:dmohandass997@yahoo.com \\ (Received $10^{\text {th }}$ May 2015; accepted $12^{\text {th }}$ Aug 2016)
}

\begin{abstract}
Livestock grazing is a major anthropogenic impact influencing both grasslands and wetlands of the world which often results in the alteration of the structure, diversity and functioning of the plant communities. Here, we seek to understand how grazing intensity influences swamp vegetation, with an emphasis on their diversity, structure and function. Six swamps were selected, two each in high, moderate and low intensity grazing sites, from the tropical montane swamps of the Upper Nilgiri Mountains, southern India. We recorded a total of 78 species belonging to 63 genera and 31 families. Our results showed that species richness, abundance and species composition differed significantly across grazing treatments. Moreover, mean vegetation cover and mean height differed significantly across grazing treatments, indicating that grazing significantly affected the vegetation structure and growth of swamp plant communities. Species compositional patterns showed that moderately grazed plant communities were significantly different from low and high grazing sites. In summary, grazing intensity influenced swamp species richness, abundance, and swamp plant communities. Specifically, high grazing pressure reduced vegetation cover causing changes in swamp community structure leading to the gradual conversion of the swamp habitat into grasslands.
\end{abstract}

Keywords: disturbance, grasslands, herbivores, high-altitude, swamp structure, vegetation cover

\section{Introduction}

Grazing by large herbivores plays a key role in maintaining the diversity, structure and function of many terrestrial ecosystems (Dahwa et al., 2013; Howland et al., 2014; Freitas et al., 2014; Ingerpuu and Sarv, 2015). However, excessive grazing can result in the ecological disturbance of vulnerable grassland and wetland ecosystems leading to biodiversity loss and biological invasions (Milchunas and Lauenroth, 1993; Perevolotsky and Seligman, 1998; Marty, 2005; Dahwa et al., 2013). Thus the response of local and regional biodiversity to grazing may be positive or negative depending upon its intensity and frequency and the species specific responses of the constituent 
vegetative and herbivore taxa (Freilich et al., 2003; Maestas et al., 2003). For instance, in the absence of large herbivores that historically grazed most grassland, livestock can serve as their functional equivalents assisting in the maintenance of localized biodiversity (Maestas et al., 2003; Marty, 2005).

Several studies have demonstrated that grazing intensity is one of the main drivers of wetland ecosystem dynamics (Marty, 2005; Jones et al., 2011; Dahwa et al., 2013). For instance, high grazing intensity is strongly correlated with high plant mortality and low recruitment rates, leading to changes in community structure and loss of species diversity (Milchunas et al., 1988; Gordon et al., 2004; Mysterud, 2006). Biophysical and ecological changes imposed by high grazing intensity may also have potential negative consequences on biodiversity and ecosystem function (Belsky and Blumenthal, 1997; Jones, 2000; Howland et al., 2014). As a result, intermediate or moderate grazing intensity is the most commonly recommended level of grazing intensity for long-term management of grasslands as it has been shown to maintain optimum species diversity at local through to global scales (Fuhlendorf and Engle, 2004; Dorrough et al., 2004). Here, we predict that swamp plant species richness, community structure and composition will be significantly altered in response to the level of grazing intensity applied.

The Upper Nilgiri Mountains of southern India hosts many wetlands (swamps) with the total area of each wetland ranging from one to 30 ha (Mohandass et al., 2014). Most of the remaining wetlands within this region are under the direct supervision of the Upper Nilgiris Protected Area Network however few are directly controlled by private companies and individuals or by native tribes and indigenous peoples. The majority of these wetlands have been converted into grasslands as a direct result of high grazing pressure due to recent human population growth and rapid agricultural expansion (Puyravaud et al., 2012; Mohandass et al., 2014). Cattle and buffaloes belonging to private land holders, native tribes and indigenous peoples are the most common herbivores grazed in wetlands. Local people and tribes use intensive grazing regimes for their domestic livestock which differ to those employed by the native wild herbivores such as elephants, sambar deer and bison. The grazing strategies employed by the local peoples and tribes can be delineated into distinct grazing intensities. For example, we define regular (daily) grazing by cattle and buffaloes to constitute high grazing intensity, occasional (weekly) grazing by cattle and buffaloes to constitute moderate grazing intensity and seasonal grazing by wild elephants, bison and sambar deer to constitute low grazing intensity. The increased intensity of anthropogenic grazing in this region has the potential to threaten native biodiversity through conversion of wetlands to grasslands. Wetland conversion would threaten the many endemic and endangered plants and native birds of this regionally unique ecosystem (Puyravaud et al., 2003; Derner et al., 2009; Mohandass, 2008; Mohandass et al., 2014).

In this study, we seek to understand how grazing intensity influences swamp vegetation, especially their resident plant diversity, structure and function. To better understand the impact of grazing on wetland vegetation within this region and design optimum conservation strategies, we aim to address the following questions: (1) How does grazing intensity influence species richness, abundance and species composition? (2) How does grazing intensity affect vegetation cover and height? (3) How does plant species similarity vary across grazing intensities? 


\section{Review of Literature}

\section{Influence of grazing on species richness, abundance and species composition}

Grazing is a disturbance which can threaten the ability of plant communities to maintain plant species richness and abundance and lead to an altered species composition (Olff and Ritchie, 1998; Walker et al., 2013; Yan et al., 2013; Török et al., 2016). Grazing alters plant diversity through mechanisms that influence local plant colonization ability and extinction dynamics (Olff and Ritchie, 1998; Alofs et al., 2014). Consequently, management of grazing has become a crucial component in efforts to restore or maintain biodiversity in particular habitats such as floodplains (Olff and Ritchie, 1998; Schaich et al., 2010). Grazing can influence species richness at both the local scale (plant neighbourhood) and the regional scale (spatial range of an individual). For instance, local disturbances and selective grazing can enhance diversity at local scales, but intense grazing can lead to strong selection for grazing tolerant plant species from within the species pool, potentially reducing diversity at larger scales (Chaneton and Facelli, 1991; Gibson and Brown, 1991; Glenn and Collins, 1992). Livestock grazing can also affect ecosystems both directly and indirectly through altering species richness and abundance on plant communities. For example, grazing was found to influence plant species richness of an alpine meadow on the eastern Tibetan Plateau via the concurrent impact of both direct and indirect pathways (Liu et al., 2012). Direct effects of grazing known to influence plant communities include mechanisms such as consumption of plant biomass including below-ground parts, trampling of plants and soil, nutrient inputs and bacterial contamination from dung and urine (Tanner, 1991). The indirect effects of grazing include influences such as reduced pollinator floral visitations, increased habitat disturbance and facilitation of species invasion (Leinaas et al., 2015; Dean et al, 2015). As such, in this study we focused on the indirect and direct effects and intensity of grazing influences on plant species richness, abundance and species composition in wetland ecosystems. Generally, the wetland habitat is highly sensitive to disturbance, with excessive disturbance resulting in reduced diversity and habitat changes. Therefore studies on the influence of grazing intensity and its indirect and direct effects on species richness and abundance can provide important insights into the maintenance and management of wetland plant communities.

Worldwide studies of the response of plant species composition and richness to livestock grazing provide inconsistent findings which vary in both their direction and extent (Waser and Price, 1981; Pandey and Singh, 1991; Belsky, 1992; Noy-Meir, 1995; Harnett et al., 1996). For instance both negative and positive diversity responses to grazing have been identified in the California grasslands (Bartolome et al., 1980, Bartolome and McClaren, 1992, Hatch et al., 1999). Analogously, in the East African highlands, the impact of grazing has not only been found to influence species richness but also the percentage cover of the dominant species thus identifying grazing induced alterations of grassland community dynamics (Taddese et al., 2002). Conversely, in Tibet, grazing exclusion decreased species richness and biodiversity by the replacement of the dominant grazing tolerant species with those of grazing sensitive competitors (such as certain graminoids) (Mayer et al., 2009; Shi et al., 2013). In addition spatial variations in the response of grasslands to grazing studies have also identified temporal variations in plant community responses. For example, Fynn et al. (2015) in their study of African wetlands, noted that intensive grazing of both wild and domestic herbivores during the dry season, did not significantly impact plant communities due to the 
prolonged recovery (grazing resting period) they experienced whilst inundated in the wet season. Consequently, the impact of grazing on plant community composition varies both regionally and temporally.

\section{The effect of grazing on plant communities and soil richness}

The impact of grazing on plant communities may be somewhat mediated by soil nutrition. For instance, Mayer et al. (2009) in a study of nutrient addition to pastures found that 19 non-enriched sites exhibited significantly lower species richness under high grazing than under low grazing. Analogously, Proulx and Mazumder (1998), in a study of grazing and soil nutrition, noted that plant species richness decreased with high grazing intensity in nutrient-poor-ecosystems, while it increased with high grazing intensity in nutrient-rich ecosystems. However, the response of plant communities to soil nutrition may vary by their residency status. For example, Dorrough (2012) in a broad-scale meta-analysis of 170 years of grazing information on Australian grasslands, noted exotic species richness declined with increasing grazing intensity whether nutrients supply was low or high, whilst native species richness declined at all spatial scales in response to increasing grazing intensity and greater resource availability (nutrient supply). Furthermore, though nutrient addition to pastures from dung and urine has been found to generally improve soil nutrient status (e.g. Tanner, 1991) this response is not always consistent with Sigua et al. (2006) noting in their study of a wetland conversion to beef cattle pasture, that this process did not function as a source of soil nutrients (especially $\mathrm{P}$ and $\mathrm{N}$ ) even with the addition of manure and urine due to the presence of grazing cattle. As such, the relationship between soil richness and grazing and the response of plant species communities is often complex and variable dependent upon the composition of the original plant community, the residency status of the current plant species within the community and the original and current soil nutrient status.

\section{Intermediate disturbance through moderate grazing and its effects on plant species richness and abundance}

Plant communities often obtain maximal species richness and abundance at moderate disturbance levels (Connell, 1978). The influence of grazing as a mechanism for plant community disturbance appears to support this general statement with many grassland communities subjected to different grazing intensities peaking in diversity at moderate grazing intensities (Patón et al., 1995; Willoughby and West, 1996; Pueyo et al., 2003; Yuan et al., 2016). For instance, Fujita et al. (2009) and Papanastasis (2009) both noted in their studies of grassland communities that moderate grazing promoted maximal community diversity. Intermediate disturbance of grassland communities through moderate grazing is suggested to results in the attention of maximal species diversity in grassland plant communities as at high levels of disturbance, species richness is low, because most species cannot tolerate frequent destructive events (e.g. Fischer and Wipf, 2002; Metera et al., 2010) whilst at low levels of disturbance (e.g. through livestock exclusion) diversity is lost through the competitive exclusion of many grassland species (Schultz et al., 2011). As such, at intermediate levels of disturbance, richness is predicted to be high, because dominant competitors and rapid colonizers are able to coexist (Chesson and Huntly, 1997; Roxburgh et al., 2004; Yuan et al., 2016). 


\section{Grazing and its effects on plant life-forms}

Grazing disturbance is known to have a differential impact on native (native plants are plants indigenous to a given area in geologic time) and exotic plants (introduced plants from other parts of the world). In general, exotic plants have been shown to be able to colonize more rapidly after disturbance than native plants (e.g. Cushman et al., 2004) allowing for their proliferation in highly-disturbed habitats. In particular, grazing is known to favor the increased dominance of exotic annual grasses at the expense of native perennial grasses (e.g. bunchgrasses) due to increased competition (Dyer and Rice, 1997; Brown and Rice, 2000). Grazing is suggested to favor exotic annual grasses, as they have higher growth rates and seed dispersal rates than perennials (Holmes and Rice, 1996). Annuals can also sustain populations in grazed landscapes by rapidly dispersing and colonizing open patches, while perennial recruitment is severely limited by defoliation and trampling (Holmes and Rice, 1996; Seabloom et al., 2003). Furthermore, an increased abundance of exotic annuals has been found to lead to the accumulation of large amounts of above-ground dead biomass which can negatively affect perennial germination, recruitment, species richness and relative dominance of native taxa (Bergelson, 1990; Facelli and Pickett, 1991; Tilman and Pacala, 1993; Foster and Gross, 1998). This enhanced exotic annual biomass also leads to positive feedbacks such as increased fire frequency and intensity that further promote exotic annual grasses (Wolkovich et al., 2009). However, whilst many perennials are outcompeted by annuals and may be recruitment limited, exotic perennials have been shown to be able to colonize more rapidly after disturbance than native perennials (Cushman et al., 2004). At a finer scale the intensity of grazing can also differentially impact native and exotic grassland species. For instance, Dorrough et al. (2007), in a broad-scale meta-analysis of 170 years of grazing information on Australian grasslands, noted that intolerant native species have been eliminated from areas that are continually and heavily grazed, whereas transient, light grazing increases richness of both exotics and natives. Consequently, plant species from different guilds of residency (native or exotic) and life-history (annual or perennial) may vary greatly in their responses to grazing and the intensity of grazing.

\section{Plant cover, plant height and grazing}

The vegetative structural trait of plant cover, i.e., the relative projected area covered by a species (Damgaard, 2014), is often used as a proxy for ecosystem health and disturbance (Damgaard, 2014) as it takes the size of individuals into account as well as their abundance. For instance, decreased plant cover in uplands or riparian areas is used to identify areas of increased runoff (Beutner and Anderson, 1943; Weaver and Rowland, 1952; Holechek et al., 1998) and decreased soil water absorption (Duley and Kelly, 1941; Hopkins, 1954), to ascertain sites with the increased potential for soil erosion (Dyksterhuis and Schmutz, 1947; Branson et al., 1981; Heady and Child, 1994). Grazing intensity can have a significant impact on the plant cover of a plant community. For instance, in an Alpine grassland of China, the cover of bare ground increased from $1.5 \%$ at the lowest level of grazing to $12.4 \%$ at high grazing intensities $(7.2 \%$ at moderate) (Haynes et al., 2012). The cover of grass, forbs and shrubs also changed over the grazing gradient with grass cover increasing and shrub cover declining due to grazing intensity (Haynes et al., 2012). Furthermore, another study by Yan and Lu 
(2015) also noted the link between overgrazing and a decline in vegetation cover and biomass (Yan and Lu, 2015) whilst several other studies suggest that grazing exclusion can result in the improvement of grass cover (Mata-Gonzalez et al., 2007; Mofidi et al., 2013). It is therefore important to assess the impact of grazing on vegetation cover especially to allow for future sustainable grazing management.

\section{The influence of grazing on species community composition and similarity}

Grazing by livestock is the main anthropogenic disturbance of native grasslands (Yan et al., 2013) and it plays an important role in determining species composition and plant species diversity (Milchunas et al., 1988, 1989). For instance, grazing intensity is well known to cause changes in the species composition of plant communities (Ren et al., 2012). However, several studies have indicated that the impact of long-term grazing can be variable in its effect on the species diversity of plant communities in grasslands with both positive and negative responses being previously identified (Bullock et al., 2001; Grace et al., 2007). However, as mentioned grazing at moderate intensity has been found to potentially promote increased species diversity (Connell, 1978; Sasaki et al., 2008). Yet, irrespective of species diversity, the species composition of grazed communities is well known to be herbivore mediated as herbivores selectively graze plant species (Bagchi et al., 2012), which are differentially impacted by defoliation (Archer and Smeins, 1991). For instance, in a tallgrass prairie, it was found that increased livestock density decreased the abundance of the highly-palatable, dominant perennial tall grass species and increased the abundance of the less-palatable $\mathrm{C}_{4}$ perennial mid-grasses (Hickman et al., 2004). Furthermore whilst the abundance of annual forbs varied across years due to grazing treatments, annual forbs obtained their highest abundances under moderate grazing stocking intensities (Hickman et al., 2004). Analogously, the similarity of a grassland species community across a large region often changes due to grazing intensity. For example, across a large study region, Haynes et al. (2012) demonstrated that grazing strongly modified plant community composition due to the selection of palatable plants, with species diversity declining under increased grazing intensity. Similarly, Török et al. (2016) found a marked difference in species composition under very high grazing intensity. Conversely, Golodets et al. (2010) identified species similarity increasing between vegetation on sites recently from which grazing had been recently excluded. As such, identifying the impact of grazing intensity on the similarity of species composition between samples allows for the determination of grazing impact but also species turnover between plots and sites (Nekola and White, 1999).

In conclusion, understanding the complex influence of grazing intensity on species richness, abundance, species composition, vegetation cover, growth height and species compositional patterns provides an important insight into the ecosystem functioning of swamp plant communities in the high altitude region of Nilgiri Mountains, southern India.

\section{Materials and methods}

\section{Study area}

Our study was carried out in the tropical montane swamps of the Upper Nilgiri Mountains, Korakundah and Upper Bhavani regions, southern India. This region lies 
between latitude $11^{\circ} 13^{\prime} \mathrm{N}$ and longitude $76^{\circ} 35^{\prime} \mathrm{E}$ with altitudes ranging from $2100 \mathrm{~m}$ to $2400 \mathrm{~m}$ above sea level (Fig. 1). The mean annual rainfall recorded at Korakundah tea estate during a period of 10 years (1993-2006) was $1887 \mathrm{~mm}$. Further detailed climatic and geological information for the study region is available from previous studies (Caner et al., 2007; Puyravaud et al., 2012; Mohandass, 2013). Swamps (Wetlands) in this region are generally flat-tabled, occurring in depressions between slopes and grasslands. Though most of these swamps are small in area and isolated from each other, a few large swamps do exist. Swamp location is a reflection of local topography coupled with drainage and local climate, and therefore can only occur in specific, limited sites (Mohandass et al., 2014). Historically, swamps within the study region occurred alongside montane forests and grasslands. However, by the late 1950s, most of the grasslands were converted into exotic plantations of Acacia dealbata Link. and Eucalyptus globulus Labill. Additionally, Pinus patula Schiede ex Schltdl. \& Cham continues to be planted in the vicinity of the remaining swamps. As a consequence of these modifications, the local swamp ecosystems are more vulnerable to disturbance and colonization by grassland species and invasive alien species. Though a majority of the forest areas in the Upper Nilgiris is protected under the Reserve Forest and National Conservation Park network (Puyravaud and Davidar, 2013), some swamps have already been converted into grasslands due to heavy grazing and rapid agriculture expansion. These human activities are driven by increasing population growth and the need to improve livelihood through additional income generating activities such as diary production.

\section{Grazing intensity}

The local indigenous tribes (Toda) and other inhabitants live close to these protected swamp areas and own cattle and buffaloes which they graze. Buffaloes have a long grazing history in this region, though usually in small populations, whilst cattle grazing is a relatively recent phenomenon, with stocking of large populations the norm. The local people exhibit preferences for grazing location within the region which focus on grazing swamps, grasslands or edges of the montane forests. Wild herbivores including elephant, sambar deer and bison are also known to graze on the swamps. Based on the historical information, interviews with indigenous people, direct field observations and expert opinions, we came up with the following categories to depict grazing intensity at the studied swamps; (i) High grazing intensity; continuous (regular) grazing by both cattle and buffaloes usually at sites located closer to villages. (ii) Moderate grazing intensity; occasional (irregular) grazing by both cattle and buffaloes with sites usually located farther from villages. (iii) Low grazing intensity; seasonal grazing by wild herbivores like elephants, deer and bison, with sites located much farther from villages.

\section{Vegetation sampling}

Six swamps were selected for examination, two in each of the high, moderate and low grazing intensity regimes. Five of the sites were in the Korakundah region while one was in the Upper Bhavani region (Fig. 1). The geographical coordinates (latitude and longitude) and altitude of each site was recorded with a GPS and the total area of each site was estimated using GIS analysis (Fig. 1; Table 1). At each site, three 1 x 60 $\mathrm{m}$ transects were randomly laid within the swamps, with transect direction 
randomized. To provide independence, the distance between each transect was a minimum of 50 metres. All plants within each transect were surveyed, recorded and collected for further plant identification (Puyravaud et al., 2012; Mohandass et al., 2014). Voucher specimens of all plant samples were collected and identification to species level was undertaken using various regional floras (Fyson, 1932; Gamble, 1915-1935; Bor, 1960) with specimen identification confirmed by the herbarium of the Botanical Survey of India, Southern Circle, Coimbatore (Mohandass, 2008; Mohandass et al., 2014). All plant names followed the nomenclature of the APG III plant classification system (Bremer et al., 2009). Along the transects, $1 \mathrm{~m}^{2}$ quadrats were placed at one metre intervals. Within each quadrat of $1 \mathrm{~m}^{2}$, the number and abundance of each species encountered was recorded. The percentage cover (hereafter called "cover") of all existed species within the quadrat, was visually estimated as percentage cover (Puyravaud et al., 2012; Dengler et al., 2012; Walker et al., 2013) with class delineation as follows: 0 - $1 \%, 1-10 \%, 10-25 \%, 25-50 \%, 50$ - $75 \%$, and above $75 \%$ based on the area individual species occupied within the $1 \mathrm{~m}^{2}$ quadrat. If one species occupied the whole area of $1 \mathrm{~m}^{2}$ it was recorded within the above $75 \%$ category of plant cover. Maximum height (centimeter) of all plant species present within the $1 \mathrm{~m}^{2}$ plots was measured with a steel tape (Puyravaud et al., 2012). Additionally, the habit (life-form) of all species within each transect was recorded.

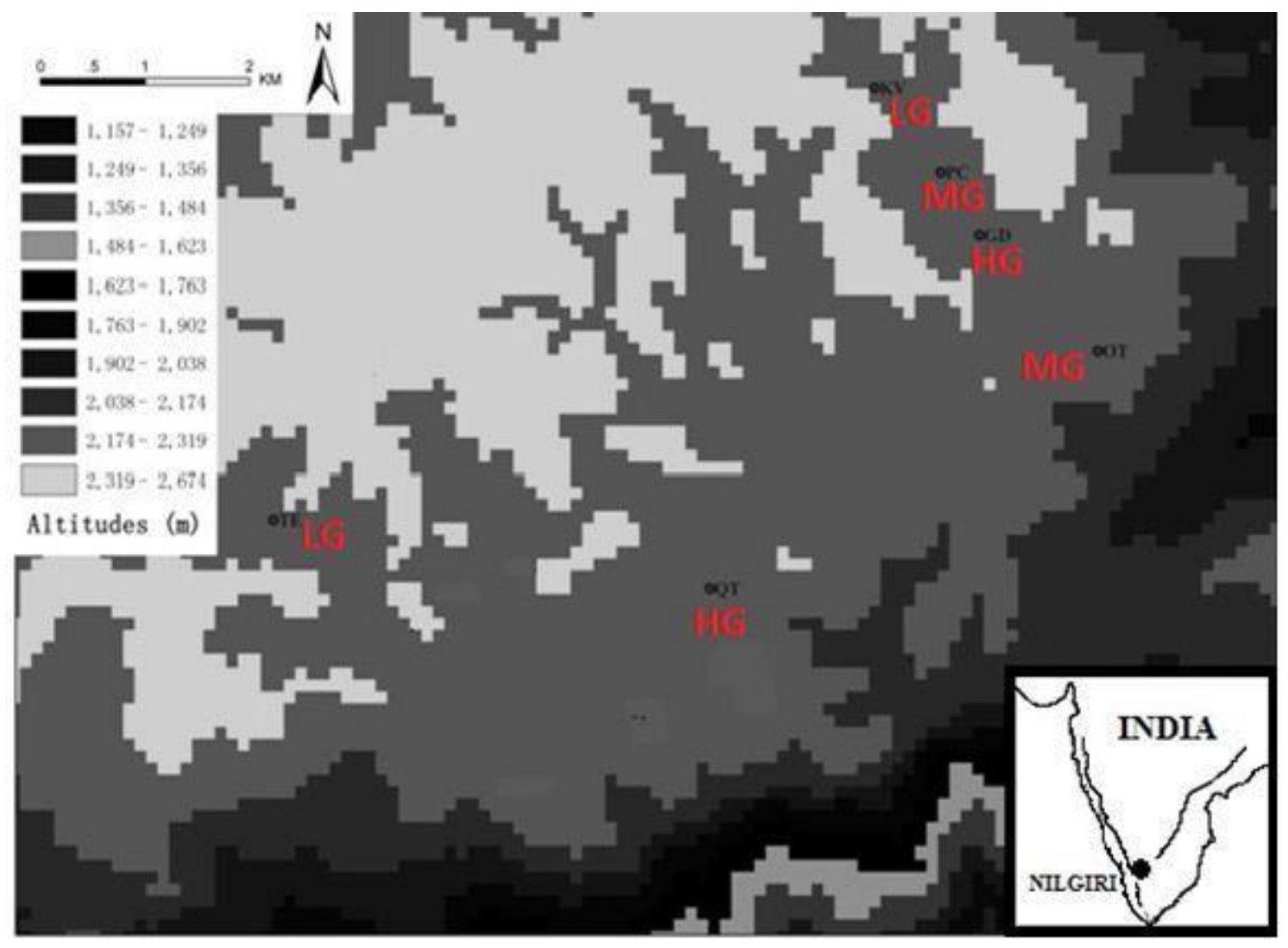

Figure 1. The geographic and altitudinal distribution of the six studied swamps with site codes denoting grazing intensity (HG-high grazing, MG-moderate grazing and LG-low grazing), Nilgiri Mountains, southern India. 
Table 1. Geographical, environmental and management characteristics of the six studied swamps, Nilgiri Mountains, southern India

\begin{tabular}{|c|c|c|c|c|c|c|c|c|c|c|}
\hline Site code & $\begin{array}{l}\text { Geographical } \\
\text { coordinates }\end{array}$ & $\begin{array}{c}\text { Altitude } \\
\text { (m) }\end{array}$ & $\begin{array}{l}\text { Total } \\
\text { area } \\
\text { (ha) }\end{array}$ & $\begin{array}{c}\text { Total } \\
\text { species } \\
\text { richness }\end{array}$ & $\begin{array}{c}\text { Total } \\
\text { abundance }\end{array}$ & $\begin{array}{l}\text { Number } \\
\text { of forbs }\end{array}$ & $\begin{array}{l}\text { Number } \\
\text { of grass }\end{array}$ & $\begin{array}{l}\text { Number } \\
\text { of } \\
\text { vine/tree } \\
\text { species }\end{array}$ & Grazing Intensity & Grazing assessment \\
\hline GD & $\begin{array}{l}11^{\circ} 14.367 \mathrm{~N} \\
76^{\circ} 35.657 \mathrm{E}\end{array}$ & 2236 & 0.8 & 27 & 701 & 15 & 11 & 1 & High grazing & $\begin{array}{c}\text { Regularly grazed by } \\
\text { cattle and buffaloes } \\
\text { located nearby human } \\
\text { habitation, }\end{array}$ \\
\hline QT & $\begin{array}{l}11^{\circ} 12.898 \mathrm{~N} \\
76^{\circ} 34.482 \mathrm{E}\end{array}$ & 2215 & 3.3 & 43 & 913 & 26 & 16 & 1 & High grazing & $\begin{array}{l}\text { Regularly grazed by } \\
\text { cattle and buffaloes } \\
\text { (daily grazing) located } \\
\text { nearby human habitation, }\end{array}$ \\
\hline $\mathrm{KV}$ & $\begin{array}{l}11^{\circ} 14.978 \mathrm{~N} \\
76^{\circ} 35.200 \mathrm{E}\end{array}$ & 2279 & 6 & 41 & 1506 & 26 & 15 & 0 & Low grazing & $\begin{array}{l}\text { Regular grazing by cattle } \\
\text { and located away from } \\
\text { human habitation, } \\
\text { Seasonally grazed by } \\
\text { elephants }\end{array}$ \\
\hline TE & $\begin{array}{l}11^{\circ} 13.186 \mathrm{~N} \\
76^{\circ} 32.581 \mathrm{E}\end{array}$ & 2259 & 1.8 & 29 & 1469 & 13 & 14 & 2 & Low grazing & $\begin{array}{l}\text { Not regularly grazed by } \\
\text { cattle and buffaloes and } \\
\text { located away from } \\
\text { human habitation, } \\
\text { Seasonally grazed by } \\
\text { elephants and bison }\end{array}$ \\
\hline OT & $\begin{array}{l}11^{\circ} 13.889 \mathrm{~N} \\
76^{\circ} 36.173 \mathrm{E}\end{array}$ & 2218 & 2.8 & 43 & 1291 & 22 & 20 & 1 & Moderate grazing & $\begin{array}{l}\text { Irregularly grazed by } \\
\text { cattle and buffaloes and } \\
\text { located nearby human } \\
\text { habitation }\end{array}$ \\
\hline $\mathrm{PC}$ & $\begin{array}{l}11^{\circ} 14.632 \mathrm{~N} \\
76^{\circ} 35.488 \mathrm{E}\end{array}$ & 2258 & 0.9 & 41 & 1401 & 25 & 16 & 0 & Moderate grazing & $\begin{array}{c}\text { Irregularly grazed by } \\
\text { cattle and buffaloes and } \\
\text { located nearby human } \\
\text { habitation }\end{array}$ \\
\hline
\end{tabular}




\section{Life-forms}

Plant habits were determined in the field through direct observation of the morphological and vegetative characters of the examined plant. These characters were defined as follows; (i) Forb/herb: Vascular plant without significant woody tissue above or below the ground and may be annual, or perennial having perennating buds borne above or below the ground (ii) Graminoid: Grass or grass-like plant, within the families Poaceae, Cyperaceae or Juncaceae. (iii) Tree: Perennial, woody plant with a single stem (trunk), normally taller than 4 to $5 \mathrm{~m}$ in height (iv) Vine: Twining/climbing plant with relatively long stems, can be woody or herbaceous (Rogers and Hartnett, 2001).

\section{Plant geographic ranges}

Assessment of the geographic range of each plant species was done using a literature survey (Fyson, 1932; Gamble, 1915-1935; Bor, 1960; Ahmedullah and Nayar, 1986). We defined narrow geographic range species as those distributed in the Nilgiri/Palni hills and adjacent areas of the Western Ghats. Species distributed within the Indian subcontinent, Sri Lanka and beyond, were considered to have a wide geographic range (Mohandass, 2008).

\section{Habitat preference}

Species habitat preference was recorded through direct observation of presence in any of the three habitats (swamps, grasslands and montane forests) with identification based on published floras (Fyson, 1932; Gamble, 1915-1935; Matthew, 1999). We then classified all species as occurring within four types of habitats as follows (i) Grassland: species found exclusively in grasslands. (ii) Grassland/Swamps: species found in both swamps and grasslands. (iii) Forest/Grassland: Species found in both forests and grasslands (iv) Swamps: Species only found in swamps.

\section{Definitions}

Species richness: we defined as the number of species per unit area (Wenhong, 2007; Brown et al., 2007) within the swamps.

Species abundance: we defined as the number of individuals per species (Magurran, 2004; Yañez-Arenas et al., 2014) in a given population.

Species composition: Species composition was defined as the contribution of each plant species per swamp and was calculated based on species richness and abundance as follows: Species composition $(\%)=$ number of species in each swamp/total number of individuals $\times 100$ (Darell and Cronberg, 2011; Økland et al., 2003).

Species similarity (of swamps): we defined as a measure of the distance, based on species composition, between all pairs of grazing sites. Here we used presence/absence of abundance data to test for the species similarity composition (Magurran, 2004; Chao et al., 2005).

\section{Data Analysis}

We calculated the total number of species (species richness) and their abundance using data from the pooled three transects per swamp across six sampled swamps. We then used these data to calculate the mean abundance of species distributed across the three separate grazing intensity categories. Species composition was defined as the 
contribution of each plant species per swamp and was calculated based on species richness and abundance as follows: Species composition $(\%)=$ number of species in each swamp/total number of individuals $\times 100$. We also calculated the mean percentage of ground cover present and mean plant growth height for each of the three grazing treatments. We compared the total species composition and species composition of lifeforms across the three grazing treatments using Analysis of variance (ANOVA). We also used ANOVA to compare the mean percentage cover and mean plant height $(\mathrm{cm})$ of the three grazing treatments. We used principal component analysis in Spatial Analysis for Macroecology (Rangel et al., 2010), followed by ANOSIM to determine if swamp plant community composition varied significantly across grazing treatments. The degree of similarity in swamp plant community composition was analyzed using ANOSIM in PAST (http://folk.uio.no/ohammer/past/) following the Bray-Curtis method. We also tested the species similarity distance shared by grazing intensities using the Bray-Curtis similarity index. The proportionate species richness and abundance of swamp plants in relation to their distribution characteristics and habitat preference were tested using Chi-square with their proportionate values subsequently compared between grazing intensities. All the statistical analyses were performed using the statistical software R Core Team (2012) version 2.15.3. and the package PAST version 3.01 (Hammer et al., 2001).

\section{Results}

\section{Species richness and composition}

We recorded a total of 78 species belonging to 63 genera and 31 families. Of the recorded species, 49 were forbs/herbs, 26 were graminoids, two were trees and one was a vine. In the high grazing intensity sites 53 species were recorded including: 37 forbs/herbs, 25 graminoids and a vine species. In the moderate grazing intensity sites 63 species were recorded including: 34 forbs/herbs, 25 graminoids and one vine species. In the low grazing intensity sites 48 species were recorded including: 27 forbs/herbs, 19 graminoids and two tree species (see Appendix 1).

\section{The effect of grazing intensity on plant species richness, abundance and community composition}

Species richness differed significantly across grazing intensity treatments $\left(\mathrm{F}_{3,18}=\right.$ $3.75, \mathrm{P}=0.047$; Fig. $2 A$ ). Total species richness within the moderate grazing intensity treatment was significantly higher than that of both the high and low grazing treatments $(\mathrm{t}=12.4, \mathrm{P}=0.0006$; Fig. 2A). Species abundance also differed significantly across grazing intensities $\left(\mathrm{F}_{3,18}=25.63, \mathrm{P}=0.0001\right)$. Total abundance in moderate grazing sites was again significantly higher than that in both the high and low grazing ( $\mathrm{t}$-test $=$ 10.71, $\mathrm{P}=0.008$, Fig. 2B). Total species composition also significantly differed between the different grazing intensity treatments $\left(\mathrm{F}_{3,17}=10.62, \mathrm{P}=0.001 ;\right.$ Fig. 3A). However, species composition of forbs did not differ significantly $\left(\mathrm{F}_{3,17}=2.32 ; \mathrm{P}=\right.$ 0.132), whereas graminoids differed significantly $\left(\mathrm{F}_{3,17}=17.55, \mathrm{P}=0.0001\right.$, respectively) in response to grazing intensity treatments (Fig. 3B). Furthermore, high grazing intensity was found to influence the dominance of grasses such as Andropogon polyptychus, Eriochyrsis rangacharii by decreasing their abundance g (Appendix 2). 

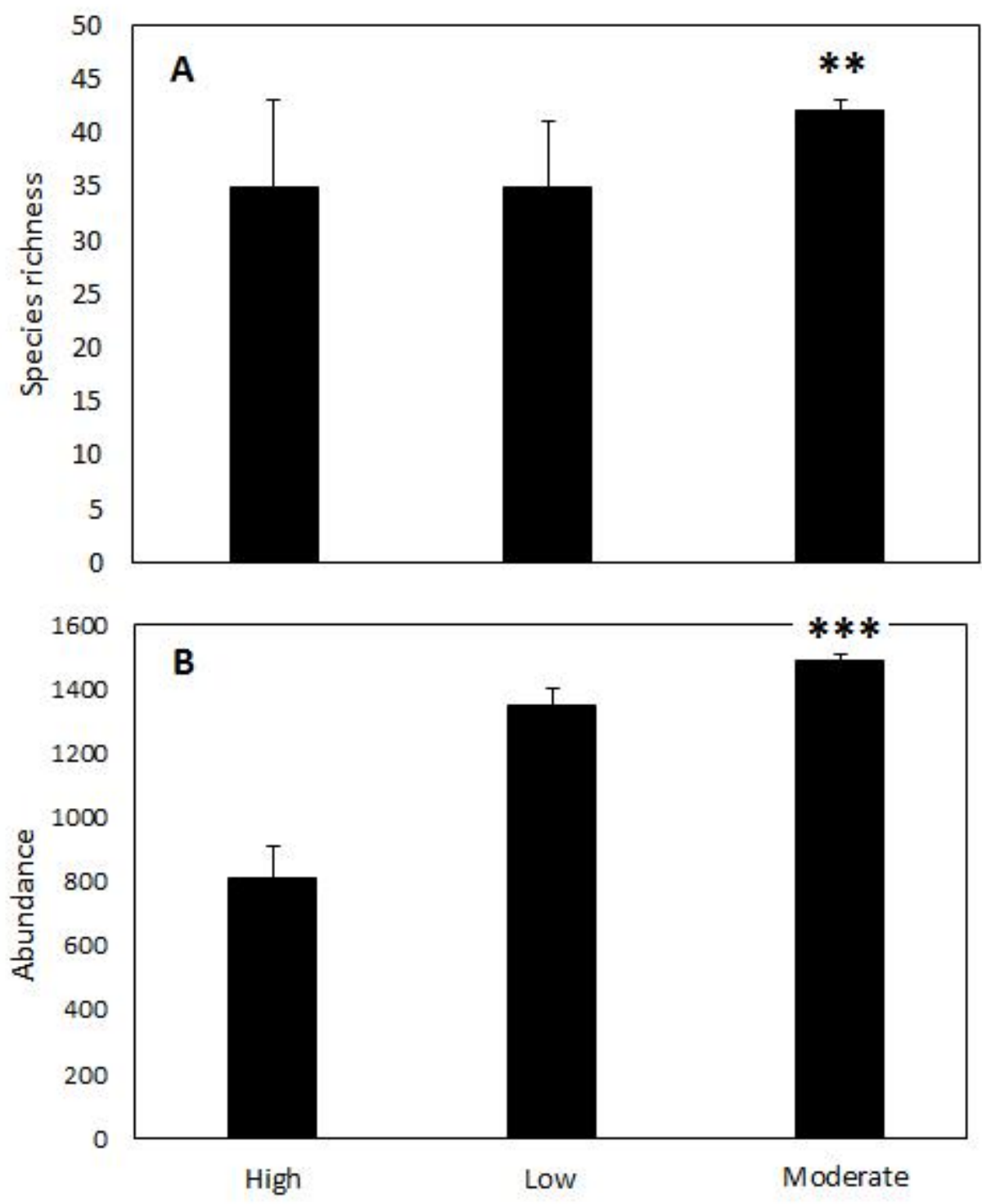

Figure 2. The impact of grazing intensity on the (A) total number of species and (B) total abundance of plants in the examined swamps, Nilgiri Mountains, southern India. (Significant values: Species richness $* * P<0.001$; abundance $* * * P<0.001)$.

\section{The effects of grazing intensity on vegetation cover and height of plant communities}

The mean percentage cover of plants signficantly differed $\left(\mathrm{F}_{3,17}=20.75, \mathrm{P}=0.0003\right)$ between grazing treatments with the percentage cover of high-grazing intensity sites significantly lower than that of both moderate and low grazing intensity sites (Moderate: Tukey's HSD comparison $=4.00 ; \mathrm{P}=0.04$; Low: 9.09, $\mathrm{P}=0.0004$; Fig. $4 A$ ). Additionally, the mean percentage of plant cover found at moderate grazing intensity sites was significantly lower than that of low grazing intensity sites (Tukey's HSD comparison = 5.08; $\mathrm{P}$ 0.013).

The mean vegetation height was significantly different $\left(\mathrm{F}_{3,17}=6.15, \mathrm{P}=0.018\right)$ between the grazing intensity treatments. Mean height was significantly lower in high grazing intensity sites than that of low grazing intensity sites (Tukey's HSD 
comparison $=4.76, \mathrm{P}=0.02$ ). However there was no significant difference in mean vegetation height between the high and moderate grazing intensity treatments (Tukey's HSD comparison $=3.602, \mathrm{P}=0.068)$, and between the moderate and low grazing intensity treatments (Tukey's HSD comparison $=1.154, \mathrm{P}=0.702)($ Fig. 4B).
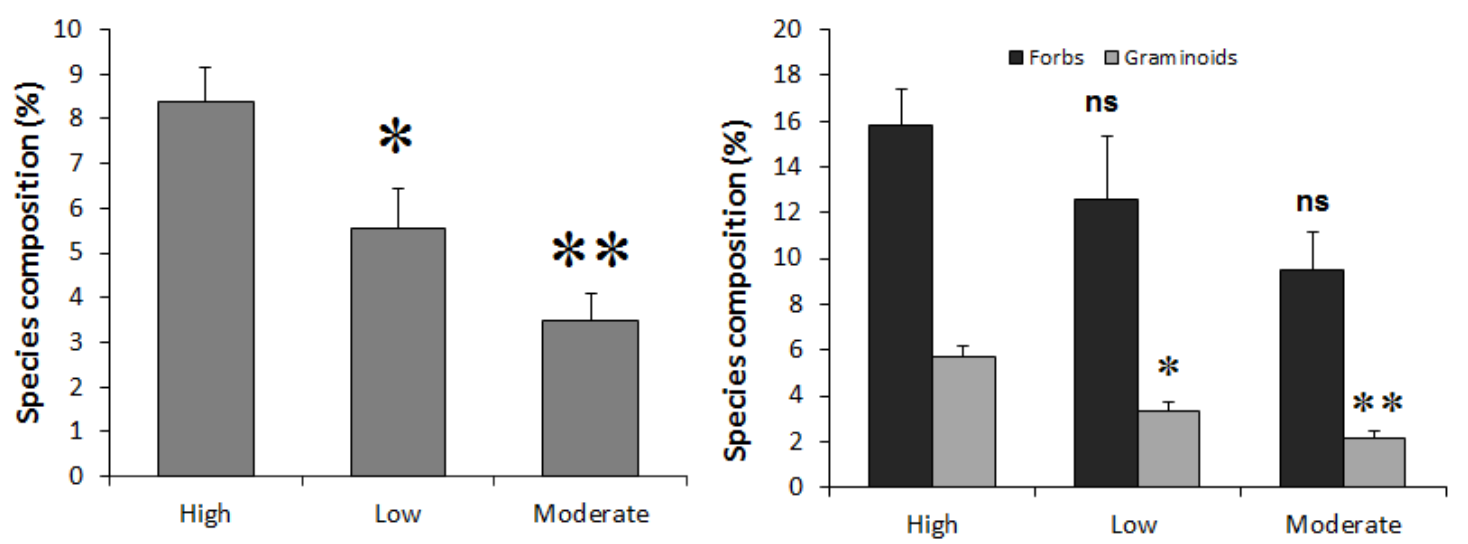

Figure 3. The impact of grazing intensity on species composition (number of species in each swamp/total number of individuals' $\times 100)$ for (A) all species combined and (B) across growthforms in the studied swamps, Nilgiri Mountains, southern India. The mean species composition was not significantly different between all species and life-forms (significant level $*<0.05 ; * *<$ 0.001; $n s=$ not significant).
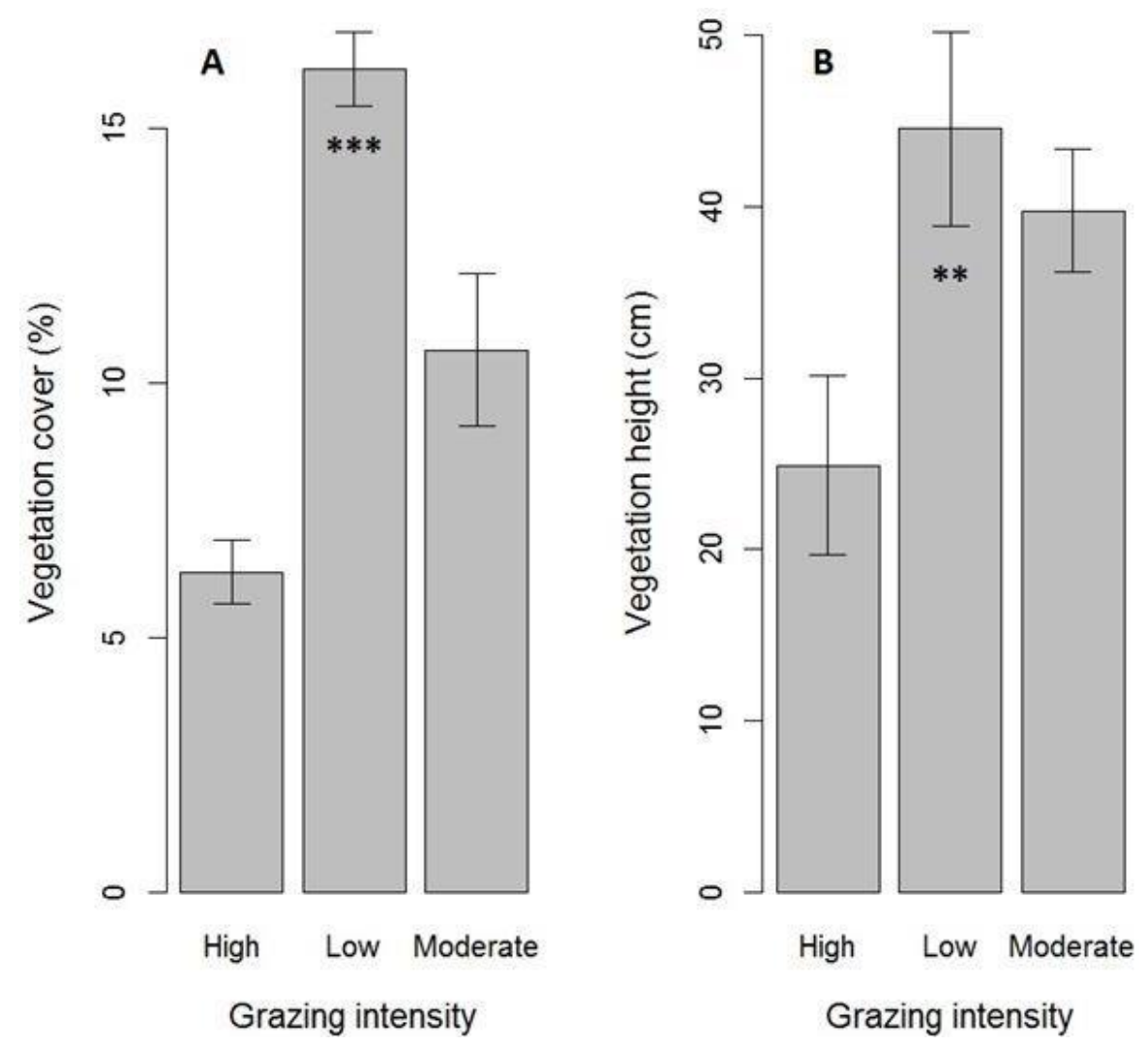

Figure 4. The effect of grazing intensity on the mean percentage vegetation cover and mean vegetation height $(\mathrm{cm})$ of the studied swamps, Nilgiri Mountains, southern India. Significant values: Vegetation cover $* * * P<0.001$; mean height $* * P<0.01)$. 


\section{The effects of grazing intensity on vegetation cover and height of the different growth-forms}

The mean forb/herb cover differed significantly $\left(\mathrm{F}_{3,17}=23.92, \mathrm{P}=0.00015\right)$ between the grazing intensity treatments. Low grazing intensity sites showed signficantly higher forb/herbs cover than that of high and moderate grazing intensity sites (Tukey's HSD comparisons $=9.68, \mathrm{P}=0.0003$; Tukey's HSD comparison $=6.053, \mathrm{P}=0.0043$, respectively). Likewise, the mean graminoid cover differed significantly $\left(\mathrm{F}_{3,17}=27.48\right.$, $\mathrm{P}=0.0001$ ) across grazing intensity treatments. Similar to forb/herb cover, graminoid cover was also signficantly higher in the low grazing intensity sites than in both the high and moderate grazing intensity sites (Tukey's HSD comparison $=10.42, \mathrm{P}=0.0003$; Tukey's HSD $=6.18, \mathrm{P} 0.0038$, respectively) (Fig. 5A). Conversely, the mean percentage cover of trees/vines did not differ signficantly $\left(\mathrm{F}_{3,17}=0.846, \mathrm{P}=0.448\right)$ between the grazing intensity treatments.

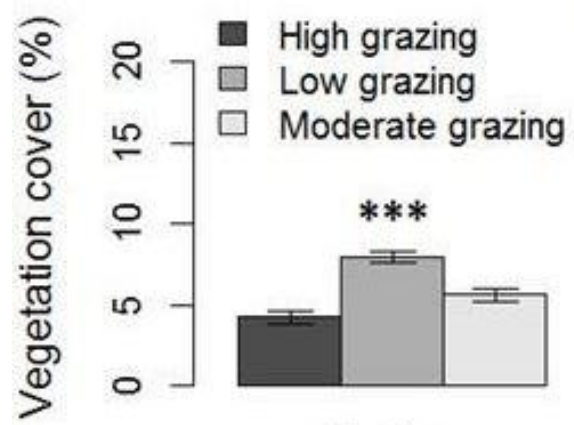

Forbs

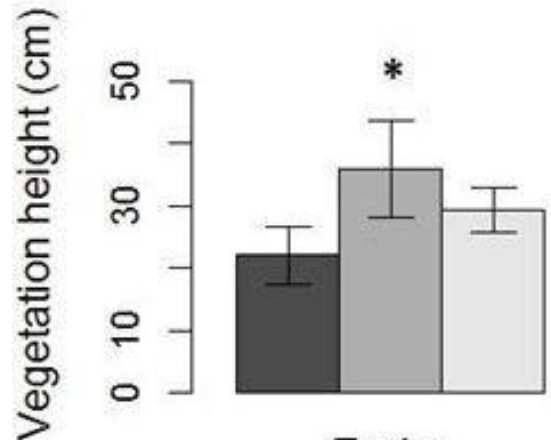

Forbs
A

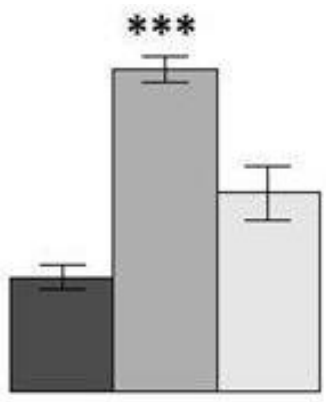

Graminoids

B

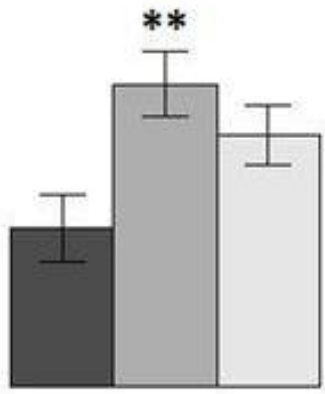

Graminoids ns

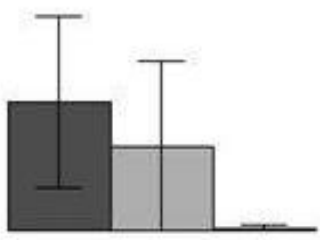

Trees/vines

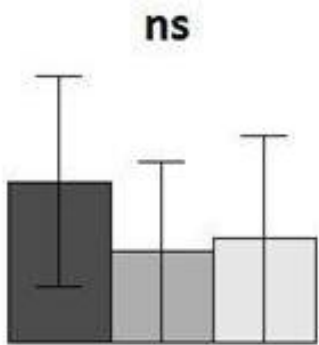

Trees/vines

\section{Life-form}

Figure 5. The impact of grazing intensity on $(A)$ mean percentage vegetation cover and $(B)$ mean vegetation height across the examined growth-forms in the swamps of the Nilgiri Mountains, southern India. (Significant values: Vegetation cover (\%);Forbs/Herbs: Tukey $H S D * * * P<0.001$; Graminoids: Tukey HSD ***P < 0.001; Tree/Vine: not significant; Mean height (cm) Forbs: Tukey HSD * P < 0.05; Graminoids: Tukey HSD ** P < 0.01; Tree/Vine: not significant; Std. error bars represents for comparison of each grazing intensity).

The mean height of both the forb/herbs and graminoids growth forms differed significantly $\left(\mathrm{F}_{3,17}=4.37, \mathrm{P}=0.043 ; \mathrm{F}_{3,17}=5.92, \mathrm{P}=0.02\right)$ between the grazing intensity treatments. Low grazing intensity sites showed a significant increase in the 
mean height of both the forb/herbs and graminoids growth forms when compared to the high grazing intensity treatment (Tukey's HSD $=4.18, \mathrm{P}=0.035$; for graminoids Tukey's $=4.8, \mathrm{P}=0.017$ ). However, the mean height of the forb/herbs and graminoids growth form groups in the moderate grazing intensity sites was not significantly different from that of the other grazing intensity treatments (Fig. 5B). Finally, the mean height of tree/vine growth form group did not differ signficantly $\left(F_{3,17}=0.139, \mathrm{P}=\right.$ 0.87 ) between the grazing intensity treatments.

\section{Species similarity between grazing intensities}

The species similarity shared across the different grazing intensity treatments was 40\% (Bray-Curtis value index $=0.41$ (Fig. 6). Sites with a moderate grazing intensity had a significantly different herbaceous community (Bray-Curtis similarity $\mathrm{R}=0.213, \mathrm{P}$ $=0.0004$ ) to those sites with high and low grazing intensities (For moderate: high grazing, $\mathrm{P}=0.043$, moderate: low grazing, $\mathrm{P}=0.035$, high: low grazing, $\mathrm{P}=0.144$ ). Sites with moderate grazing intensity had the highest species composition.

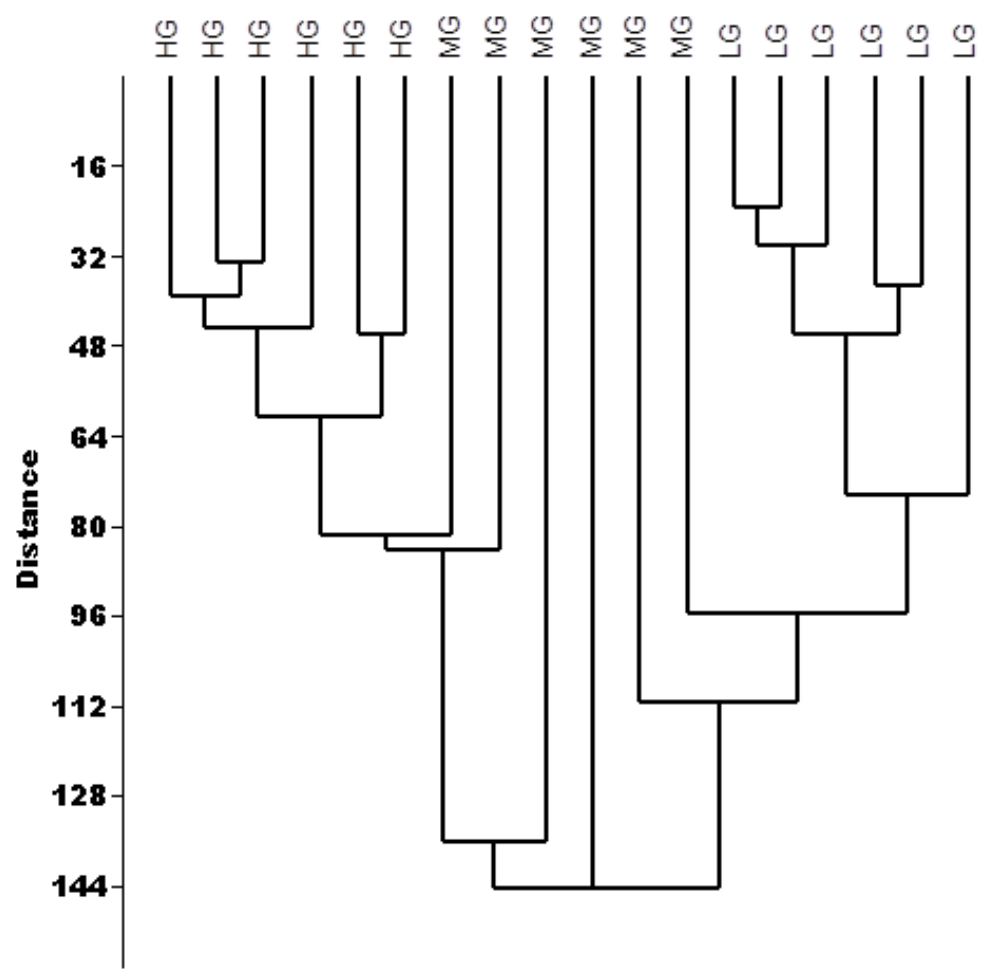

Figure 6. A Bray-Curtis distance-based species similarity analysis across the different grazing intensities (HG-High grazing; MG-Moderate grazing; LG-Low grazing) of the six studied swamps, Nilgiri Mountains, southern India.

The PCA axis I explained $72.4 \%$ of the variation, and the PCA axis II accounted for $27.6 \%$ of the variation in species communities (Fig. 7). These axes show that across the different grazing intensity treatments, the species composition is similar and they share the majority of the recorded plant species (Fig. 7). However, high and moderate grazing intensity sites still possessed an almost $25 \%$ difference in species community composition. 


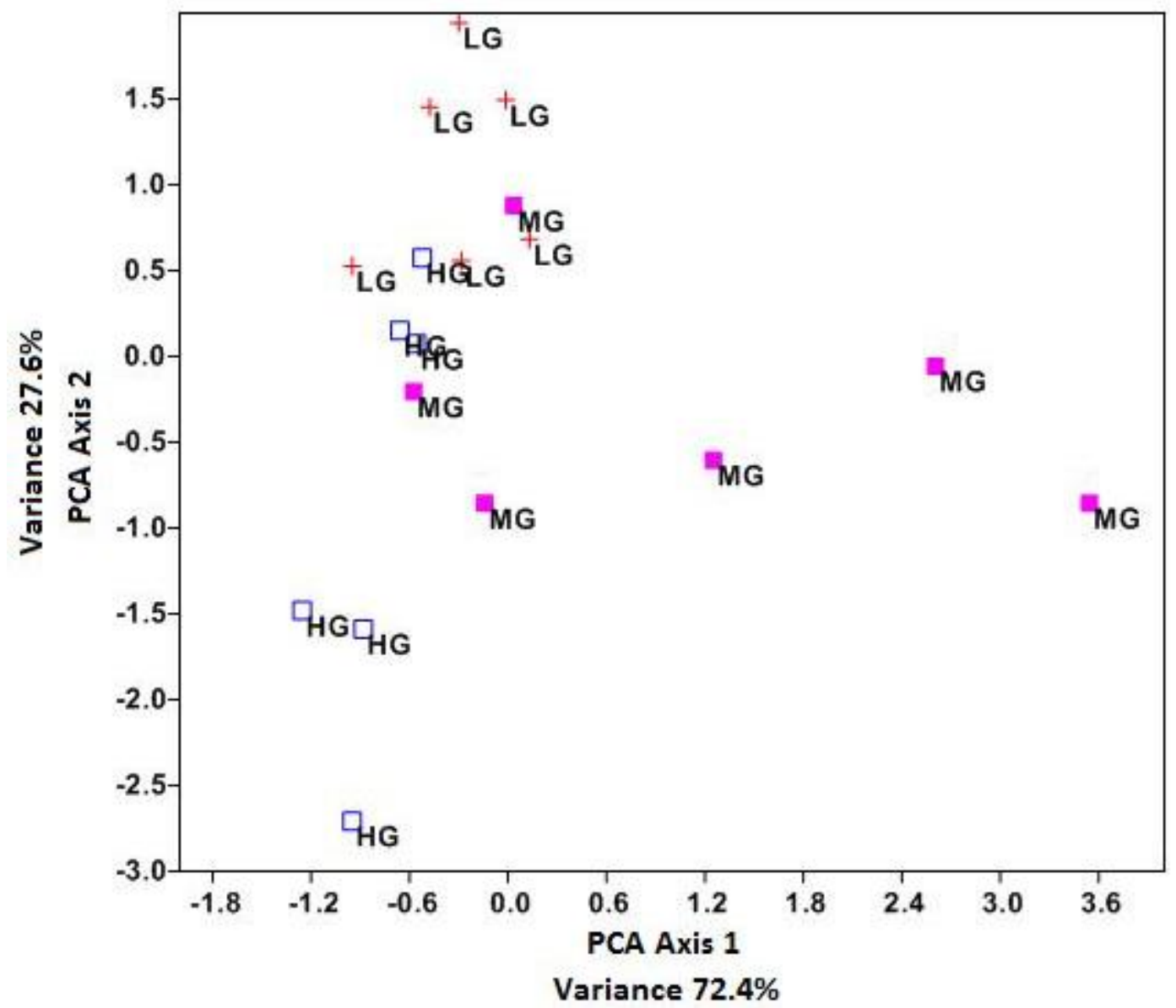

Figure 7. A Principal Component Analysis (PCA Axis I and II) of the swamp plant community composition with distributions based on their grazing intensity (HG- high grazing; $M G$ moderate grazing; LG- low grazing), Nilgiri Mountains, southern India.

\section{The effect of grazing intensity on plant geographic ranges}

The percentage of plants with a narrow geographic distribution was higher in high (54\%) and moderate intensity grazing $(67 \%)$ sites than in low grazing intensity sites $(51 \%)$. Similarly, the percentage of widespread species was higher in high (14\%) and moderate grazing (14\%) intensity sites. The percentage abundance ofident resident (local) plant species with narrow geographic distributions was higher in moderate $(35 \%)$ and low grazing (34\%) intensity sites than in high grazing $(26 \%)$ intensity sites. However, the percentage abundance of resident plant species with widespread distributions was higher in moderate grazing (2\%) than in high (1\%) and low grazing (1\%) intensity sites (Table 2).

\section{The effect of grazing intensity on plant habitat preference}

The percentage of resident grassland species was higher in swamps experiencing high and moderate intensity grazing than in those experiencing low grazing intensity. Analogously, the percentange of resident grassland/swamp classified plant species was greater in high and moderately gazed sites than inlow intensity grazed sites. The forest/grassland classified species occurred more freqently in moderately grazed sites 
when compared to high and low grazing intensity sites. Typical swamp species occurred more often in moderate and low grazing intensity sites than in high grazing intensity sites. High and moderate grazing intensity had the greatest impact upon the abundance of forest/grassland species (Table 3). Overall, among the different grazing intensities, the percentage abundance of swamp species was higher than that of forest/grassland species. Additionally, swamp species abundance was higher in moderate (29\%) and low grazing (25\%) intensity sites than in high grazing (19\%) intensity site.

Table 2. The influence of grazing intensity on the percentage of species richness and abundance of narrow and widely distributed plant species in the six studied swamps, Nilgiri Mountains, southern India.

\begin{tabular}{lcccccc}
\hline & \multicolumn{3}{c}{ Species richness } & \multicolumn{3}{c}{ Abundance } \\
\hline Plant geographic range & $\begin{array}{c}\text { High- } \\
\text { grazing }\end{array}$ & $\begin{array}{c}\text { Moderate } \\
\text {-grazing }\end{array}$ & $\begin{array}{c}\text { Low- } \\
\text { grazing }\end{array}$ & $\begin{array}{c}\text { High- } \\
\text { grazing }\end{array}$ & $\begin{array}{c}\text { Moderate- } \\
\text { grazing }\end{array}$ & $\begin{array}{c}\text { Low- } \\
\text { grazing }\end{array}$ \\
\hline Narrow & 54 & 67 & 51 & 26 & 35 & 34 \\
Wide & 14 & 14 & 10 & 1 & 2 & 1 \\
\hline
\end{tabular}

Table 3. The influence of grazing intensity on the percentage of plant species richness and abundance as a response to habitat preference (percentage) in the tropical montane swamps of the Nilgiri Mountains, southern India.

\begin{tabular}{lcccccc}
\hline & \multicolumn{3}{c}{ Species richness } & \multicolumn{3}{c}{ Abundance } \\
\hline Habitat & $\begin{array}{c}\text { High- } \\
\text { grazing }\end{array}$ & $\begin{array}{c}\text { Moderate- } \\
\text { grazing }\end{array}$ & $\begin{array}{c}\text { Low- } \\
\text { grazing }\end{array}$ & $\begin{array}{c}\text { High- } \\
\text { grazing }\end{array}$ & $\begin{array}{c}\text { Moderate- } \\
\text { grazing }\end{array}$ & $\begin{array}{c}\text { Low- } \\
\text { grazing }\end{array}$ \\
Grassland only & 17 & 17 & 8 & 2 & 2 & 1 \\
Grassland/Swamps & 14 & 15 & 12 & 4 & 6 & 5 \\
Forest/Grassland & 13 & 17 & 13 & 3 & 2 & 3 \\
Swamps & 24 & 32 & 29 & 19 & 29 & 25 \\
\hline
\end{tabular}

\section{Discussion}

Our results suggest that grazing intensity alters the species richness, abundance, species composition and growth of swamp plant communities (Fig. 2, 3, 4 and 5). Moreover, grazing intensity influences plant community composition through colonization of the swamps by species found in the surrounding vegetation species pools. This colonization indicates that changes in grazing intensity likely impacted plant species differentially through grazier preference. Overall, grazing intensity appears to alter the swamp plant community structure through inhibition of natural succession. Therefore, regularly, heavily-grazed swamps risk losing their original structure and being gradually converted into grasslands (Fig. $8 A B$ ). In this study we demonstrated how different grazing intensities influence species richness and composition, suggesting grazing functions as either a neutral or negative feedback for swamp plant community composition. 

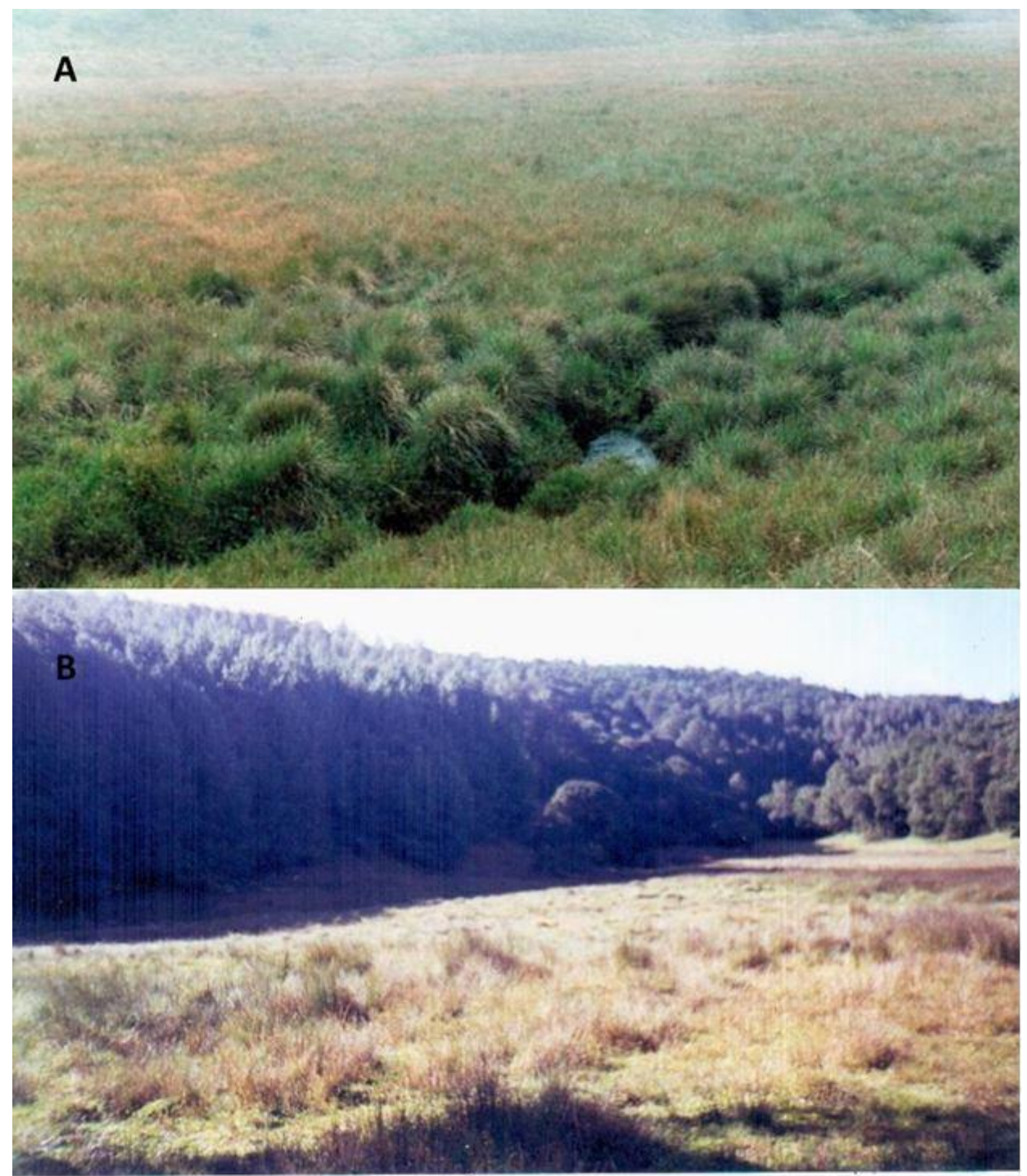

Figure 8. (A) a low grazing swamp which has not been grazed by cattle (B) a regularly grazed swamp which has now been converted into a grasslands in the Upper Nilgiri Mountains, southern India.

Previous studies of grazing intensity on the diversity of wetland and grassland ecosystems have been mixed in their findings with some reporting a positive and some a negative diversity response to intense grazing (Bullock et al., 2001; Cingolani et al., 2005; Grace et al., 2007; Ren et al., 2012). In general, however, many studies suggest that high grazing pressure likely reduces biodiversity, potentially influencing keystone species, and that biodiversity conservation benefits through reducing high level grazing to a medium grazing intensity (Jones, 2000; Davies et al., 2010). In this study, we found 
that grazing intensity significantly influence the local species composition (Fig. 3). However, species composition tends to be affected by grazing periods and timing (Smith et al., 1996). For instance, previous studies have shown that overgrazing can significantly alter species composition with edge- and slow-growing species becoming more abundant on heavily grazed sites than on less frequently grazed sites (Alder and Morales, 1999). High grazing may also play a major role in species invasions benefitting groups such as weeds and grassland species, thus greatly altering native species composition. We did however find that species abundance significantly decreased at sites of high grazing, causing changes in vegetation cover and growth of swamp communities. Thus, whilst high grazing significantly influenced the local species composition of swamps it also altered the swamp vegetation abundance and structure and create more gaps within swamp communities. As mentioned these gaps may facilitate species invasions, resulting in gap colonization by edge species causing change in swamp structure and decreased spatial heterogeneity within the swamp community (Towne and Owensby, 1984).

Grazing intensity has a species-specific effect on the abundance of plants within swamps. For instance, on based on the abundance of $>100$ individuals per species (Appendix 2), Andropogon polyptychos Steud., Cyrtococcum deccanense Bor., and Juncus effusus L. was found to occur most frequently at sites experiencing high grazing, whereas Andropogon polyptychos Steud., Eriocaulon brownianum Mart., Eriochrysis rangacharii C.E.C.Fisch., and Rhynchospora rugosa (Vahl) Gale were more common at sites experiencing moderate grazing. Furthermore, Andropogon polyptychos Steud., Eriochrysis rangacharii C.E.C.Fisch., Juncus effusus L., and Rhynchospora rugosa (Vahl) Gale more prevalent at sites under low grazing. Consequently, whilst high intensity grazing decreases species abundance responses are often species-specific though very few species (e.g. A. polyptychos, J. effusus, $R$. rugose) are tolerant to high grazing intensity. Furthermore, high grazing was found to negatively impact the endangered species E. rangacharii (Puyravaud et al., 2003).

High grazing resulted in a significant decrease in average plant height which may be a major issue for seed dispersal and plant reproduction. Generally, swamp grasses and forbs produce terminal spikes and raceme inflorescences. Grazing herbivores might consume these floral parts prior to fruit and seed production. Thus, high grazing pressure might pose negative consequences on plant reproductive success within swamp ecosystems. In addition, though species composition was not similar between high and low grazing sites (Fig. 3A), indicating that high grazing swamps maintain more species richness as compare to $\mathrm{s}$ low grazing plots, high grazing sites possessed different species assemblages than those of low grazing sites. In particular, low grazing maintained typical swamp grass/forb species, but high grazing favored grassland and invading forb species.

We found that swamps experiencing moderate grazing intensity retained species richness significantly higher than that of the low intensity grazing plots (Fig. 2). This finding supports previous studies which found that a moderate grazing intensity can promote increased species richness (Connell, 1978; Huston, 1979; Sakai et al., 2008) although others have suggested that the positive effects of grazing on species richness may have been overestimated (Sasaki et al., 2008; Sasaki et al., 2009; Auerswald et al., 2012). Here, moderate grazing of swamps supported both higher species richness and abundance than that of the high and low intensity grazed swamps. We are aware that swamp size is also an important predictor of grazing intensity. For instance, larger 
swamps exposed to moderate and high grazing levels may exhibit less significant changes in their species richness, composition and community structure than smaller swamps simply due to their higher innate levels of these variables. Unfortunately, due to the low availability of natural large swamps for surveying, we did not conduct an analysis of swamp size. However, we did find that even small sized swamps in the study region may retain relatively high species richness. Moreover, the fact that species composition was significantly lower in moderately grazed swamps of any size suggests that this level of grazing is not suitable for maintaining high swamp species composition than either high or low level grazing. However, the finding that swamp plant richness showed a positive response to moderate grazing are highly consistent with those reported by previous studies (Dorrough et al., 2004; Fuhlendorf and Engle, 2004; Sasaki et al., 2008).

The vegetation cover of the examined swamp plant community was significantly higher in the low grazing intensity sites (Fig. 4A). However, plant height did not differ significantly between low and moderately grazed swamps (Fig. 4B). These finding suggest that moderately grazed swamp plant communities lose vegetation but still retain their overall structure in responses to moderate grazing intensity. Our study supports the intermediate disturbance hypothesis (Connell, 1978) as we found negative diversity effects of low and high grazing intensity on the swamp plant communities (Ren et al., 2012). Notably, moderate grazing intensity showed significant differences in community composition when compared to high and low grazing intensity according to the examined PCA axis. Therefore, moderate grazing may aid in promoting increased between-site species diversity (beta-diversity) whilst retaining vegetation structure. However, additional sampling sites would need to occur to confirm these results.

\section{Conservation implications}

In this study, high level grazing differentially influenced plant community composition. Although, the level of grazing intensity is known to increase niche availability (Fuhlendorf and Engle, 2004) high-grazing pressure can induce a reduction in the plant population structure, affect plant growth and reproductive success and reduce species turnover. We found that high grazing intensity resulted in a negative feedback whilst moderate grazing intensity resulted in a positive feedback of diversity in the swamp plant communities. However, both high and moderate grazing promoted the influx of a high number of species which are not typical swamp species. Most of the invading species appeared to move into the swamp pool from the adjacent grassland habitat. Additionally, the surrounding vegetation of many of the studied swamps contained exotic species (such as Pinus patula, Acacia dealbata) including plantation species and invasive herbs. These undesirable species moved into the swamps as a result of high grazing pressure. Thus, as grazing intensity increases the abundance of grassland native species and exotic species into swamps it subsequently alters the swamp community composition. Therefore, for conservation purposes, there is an urgent need to prevent high-grazing activities in order to maintain native swamp species and retain biodiversity. Although switching to a moderate grazing intensity as a management strategy will not ensure conservation of swamp plant communities alone as few empirical studies provide support for grazing at moderate intensities as a means of wetlands biodiversity conservation (Dorrough et al., 2012; McIntyre et al., 2003; Beever and Brussard, 2004). Furthermore, the challenge for determining appropriate 
grazing management in the maintenance of these diverse native swamp plant communities is highlighted by the additional need to conserve endemic and endangered grass species (Puyravaud et al., 2003; Mohandass et al., 2014) within sites of moderate and low grazing intensities.

\section{Conclusion}

Our study provides important insights into the impact of large herbivory grazing pressure on swamp plant communities. Though these swamps are maintained under the protected area network strategy, the current high intensity grazing does not support sustained plant community species richness (and thus regional diversity), abundance, vegetation cover nor growth within the swamps. As such, effective management of grazing is required if the maintenance of swamp plant communities in these endangered wetland ecosystems is to occur. Notably, regular high grazing pressure by cattle and/or buffaloes must be adequately managed as it is threatening wetland conservation and resulting in the conversion of swamp habitat into grassland.

Acknowledgements. We are grateful to Dr. Jean-Philippe Puyravaud for his great support and valuable suggestions throughout the experiments. We are thankful to Dr. Qing-Jun Li for facilitating the writing of this paper. This publication was supported by the National Natural Science Foundation of China (NSFC) through a Young Scientist Grant. No. 31200173. P.R. China. We would like to thank Edhkwehlynawd Botanical Refuge (EBR) Centre Trust for funding this project. We thank Dr. Tarun Chhabra, and Mrs. Supriya Sahu (ex collector of Nilgiris), for giving us the opportunity to undertake this study. We also thank Dr. Suresh B baburaj, Head of Survey of Medicinal Plants and Collection Unit, Ootacamund, for issuing equipment and floras. We are thankful to the Tamilnadu Forest Department for granting us permission to work in the Reserved Forests, Mr. D. Hegde, Director, Chamraj Group, for logistic support and his keen interest in our efforts, Mr. M. Iqbal, and Mr. P. Dambekodi, successive Managers of the Korakundah Tea Estate and Chamraj Group, who have provided crucial help without which this study would have been impossible.

\section{REFERENCES}

[1] Adler, P., Morales, J.M. (1999): Influence of environmental factors and sheep grazing on an Andean grassland. - Journal of Range Management 52: 471-480.

[2] Alofs, K.M., González, A.V., Fowler, N.L. (2014): Local native plant diversity responds to habitat loss and fragmentation over different time spans and spatial scales. - Plant Ecology 215: 1139-1151.

[3] Archer, S., Smeins, F.E. (1991): Ecosystems-level processes, pp. 109-140. - In: Heitschmidt, R. K., Stuth, J. W. (eds.) Grazing management: An ecological perspective. Timber Press, Portland, Ore.

[4] Auerswald, K., Wittmer, M.H.O.M., Bai, Y.F., Yang H., Taube, F., Susenbeth, A., Schnyder, H. (2012): C4 abundance in an Inner Mongolia grassland system is driven by temperature - moisture interaction, not grazing pressure. - Basic and Applied Ecology 9: 1439-1791.

[5] Bartolome, J.W., Mcclaran, M.P. (1992): Composition and productivity of California oak savanna seasonally grazed by sheep. - Journal of Range Management 45:103-107

[6] Bartolome, J.M., Fehmi, J.S., Jackson, R.D., and Allen-Diaz, B. (2004). Response of a native perennial grass stand to disturbance in California's Coast Range Grassland. Restoration Ecology 12: 279-289. 
[7] Beever, E.A., Brussard, P.F. (2004): Community- and landscape-level responses of reptiles and small mammals to feral-horse grazing in the Great Basin. - Journal of Arid Environments 59: 271-297.

[8] Belsky, A.J. (1992): Effects of grazing, competition, disturbance and fire on species composition and diversity in grassland communities. - Journal of Vegetation Science 3: 187-200.

[9] Belsky, A.J., and Blumenthal, D.M. (1997): Effects of livestock grazing on stand dynamics and soils in upland forests of the Interior West. - Conservation Biology 11: 315-327.

[10] Bergelson, J. (1990): Life after death: site pre-emption by the remains of Poa annua. Ecology 71: 2157-2165.

[11] Beutner, E.L., Anderson, D. (1943): The effect of surface mulches on water production on some semidesert grassland soils. - Journal American. Society of Agronomy. 33:393400.

[12] Bullock, J.M., Franklin, J., Stevenson, M.J., Silvertown, J., Coulson, S.J., Gregory, S.J., Tofts, R. (2001): A plant trait analysis of responses to grazing in a long-term experiment. - Journal of Applied Ecology 38: 253-267.

[13] Branson, F.A., G.F. Gifford, G.F., Penfound, K.G., and R.F. Hadley, R.F. (1981):. Rangeland hydrology. - Range Sciences Series No. 1.

[14] Bremer, B., Bremer, K., Chase, M.W., Fay, M.F., Reveal, J.L., Soltis, D.E., Soltis, P.S., Stevens, P.F. (2009): An update of the Angiosperm Phylogeny Group classification for the orders and families of flowering plants: APG III. - Botanical Journal of the Linnean Society 161: 105-121.

[15] Brown, C.S., Rice, K.J. (2000): The mark of Zorro: effects of the exotic annual grass Vulpia myuros on California native perennial grasses. - Restoration Ecology 8: 10-17.

[16] Brown, R.L., Jacobs, L.A., Peet, R.K. (2007): Species richness: Small Scale. Encyclopedia of Life Sciences. doi: 10.1002/9780470015902.a0020488.

[17] Caner, L., Lo Seen, D., Gunnell, Y., Ramesh, B.R., Bourgeon G. (2007): Spatial heterogeneity of land cover response to climatic change in the Nilgiri highlands (southern India) since the last glacial maximum. - Holocene 17: 195-205.

[18] Cingolani, A.M., Noy-Meir, I., Diaz, S. (2005): Grazing effects on rangeland diversity: A synthesis of contemporary models. - Ecological Applications 15: 757-773.

[19] Chao, A., Chazdon, R.L., Colwell, R.K., T. Shen, T. (2005): A new statistical approach for assessing similarity of species composition with incidence and abundance data. Ecology Letters 8: 148-159.

[20] Chaneton, E. J., Facelli, J. M., León, R. J. C. (1988): Floristic changes induced by flooding on grazed and ungrazed low-land grasslands in Argentina. - Journal of Range Management 41: 495-499.

[21] Chesson, P., Huntly, N. (1997): The roles of harsh and fluctuating conditions in the dynamics of ecological communities. - American Naturalist 150: 519-553.

[22] Connell, J.H. (1978): Diversity in tropical rain forests and coral reefs - high diversity of trees and corals is maintained only in a non-equilibrium state. - Science 199: 1302-1310.

[23] Core Team (2012). R: A language and environment for statistical computing. R Foundation for Statistical Computing, Vienna, Austria. - ISBN 3-900051-07-0, URL http://www.R-project.org/

[24] Dahwa, E., Mudzengi, C.P., Hungwe, T., Shoko, M.D., Poshiwa, X., Kativu. S. and Murungweni, C. (2013): Influence of grazing intensity on soil properties and shaping herbaceous plant communities in Semi-Arid Dambo Wetlands of Zimbabwe. - Journal of Enviornmental Protection 4: 1181-1188.

[25] Damgaard, C. (2014): Estimating mean plant cover from different types of covers data: a coherent statistical framework. - Ecosphere 5: 1-7.

[26] Darell, P., Cronberg, N. (2011): Bryophytes in black alder swamps in south Sweden: habitat classification, environmental factors and life-strategies. - Lindbergia 34: 9-29. 
[27] Davies, K.W., Bates, J.D., Svejcar, T.J., Boyd, C.S. (2010): Effects of Long-Term Livestock Grazing on Fuel Characteristics in Rangelands: An Example From the Sagebrush Steppe. - Rangeland Ecology and Management 63: 662-669.

[28] Dean, C. E., Day, J., Gozlan, R. E., Diaz, A. (2015): Grazing vertebrates promote invasive Swamp Stonecrop (Crassula helmsii) abundance. - Invasive Plant Science and Management 8: 131-138.

[29] Derner, J.D., Lauenroth, W.K., Stapp, P., Augustine, D.J. (2009): Livestock as Ecosystem Engineers for Grassland Bird Habitat in the Western Great Plains of North America. Rangeland Ecology and Management 62: 111-118.

[30] Dorrough, J., Yen, A., Turner, V., Clark, S.G., Crosthwaite, J., Hirth, J.R. (2004): Livestock grazing management and biodiversity conservation in Australian temperate grassy landscapes. - Australian Journal of Agricultural Research 55: 279-295.

[31] Dorrough, J., McIntyre, S., Brown, G., Stol, J., Barrett, G., Brown, A. (2012): Differential responses of plants, reptiles and birds to grazing management, fertilizer and tree clearing. - Austral Ecology 37: 569-582.

[32] Duley, F.L., Kelly, L.L. (1941): Surface condition of soil and time of application as related to intake of water. U. S. Department Agriculture Circle 608.

[33] Dyer, A.R., Rice, K.J. (1997): Intraspecific and diffuse competition: the response of Nassella pulchra in a California grassland. - Ecological Application 7: 484-392.

[34] Dyksterhuis, E.J., Sehmutz, E.M. (1947): Natural mulches or litter of grasslands: with kinds and amounts on a southern prairie. - Ecology 28: 163-179.

[35] Facelli, J.M., Pickett, S.T.A. (1991): Plant litter: its dynamics and effects on plant community structure. - Botanical Review 57: 1-32

[36] Fischer, M., Wipf, S. (2002): Effect of low-intensity grazing on the species-rich vegetation of traditionally mown subalpine meadows. - Biological Conservation 104: 1-11.

[37] Foster, B.L., Gross, K.L. (1998): Species richness in a successional grassland: effects of nitrogen enrichment and plant litter. - Ecology 79: 2593-2602.

[38] Freilich, J. E., Emlen, J.M., Duda, J.J., Freeman, D.D., Cafaro. P. J. (2003): Ecological effects of ranching: a six-point critique. - BioScience 53: 759-765.

[39] Freitas, M.R., Roche, L.M., Weixelman, D., Tate, K.W.(2014): Montane Meadow Plant Community Response to Livestock Grazing. - Environmental Management. DOI 10.1007/s00267-014-0294-y.

[40] Fuhlendorf, S.D. Engle, D.M. (2004): Application of the fire-grazing interaction to restore a shifting mosaic on tallgrass prairie. - Journal of Applied Ecology 41: 604-614.

[41] Fynn, R.W.S., Murray-Hudson, M., Dhliwayo, M., Scholte, P. (2015): African wetlands and their seasonal use by wild and domestic herbivores. - Wetlands Ecology and Management 23: 559-581.

[42] Fyson, P.F. (1932): The Flora of Nilgiri and Palni Hill Tops (above 6,500 ft.) and Kodaikanal. Govt. Press, Madras. 3 Vols. 581 pages.

[43] Fujita, N., Amartuvshin N., Yamada, Y., Matsui, K., Sakai, S., Yamamura, S. (2009): Positive and negative effects of livestock grazing on plant diversity of Mongolian nomadic pasturelands along a slope with soil moisture gradient. - Grassland Science 55: 126-134.

[44] Gamble, J.S.,Fischer, C.E.C. (1915-1935): Flora of the Presidency of Madras, Volumes 1-3. Adlard \& Son Ltd, London. 1389 pages.

[45] Gibson, C.W.D., Brown, V.K. (1991): The effects of grazing on local colonisation and extinction during early succession. - Journal of Vegetation Science 2: 291-300.

[46] Glenn, S. M., Collins, S. L. (1992: Effects of spatial scale and disturbance on rates of immigration and extinction of species in prairies. - Oikos 63:273-280.

[47] Golodets, C., Kigel, J., Sternberg, M. Recovery of plant species composition and ecosystem function after cessation of grazing in a Mediterranean grassland. - Plant and Soil 329: 365-378. 
[48] Gordon, I.J., Hester, A.J., Festa-Bianchet, M. (2004): The management of wild large herbivores to meet economic, conservation and environmental objectives. - Journal of Applied Ecology 41: 1021-1031.

[49] Grace, J.B., Anderson, T.M., Smith, M.D., Seabloom, E., Andelman, S.J., Meche G., Weiher, E., Allain, L.K., Jutila, H., Sankaran, M., Knops, J., Ritchie, M., Willig, M.R. (2007): Does species diversity limit productivity in natural grassland communities? Ecology Letters 10: 680-689.

[50] Hammer, Ø., Harper, D.A.T., Ryan, P.D. (2001): Past: Paleontological statistics software package for education and data analysis. - Palaeontologia Electronica 4 (1) art. 4, 9 pp.

[51] Hatch, D.A., Bartolome, J.W., Fehmi, J.S., Hillyard, D.S. (1999): Effects of burning and grazing on a coastal California grassland. - Restoration Ecology 7: 376-381.

[52] Haynes, M.A., Fang, Z., Waller, D.M. (2012): Grazing Impacts on the Diversity and Composition of Alpine Rangelands in Northwest Yunnan. - Journal of Plant Ecology. doi: 10.1093/jpe/rts021.

[53] Heady, H. F., Child, A.D. (1994): Rangeland ecology and management. Westview Press, San Francisco, Cob.

[54] Hickman, K.R., Hartnett, D.C., Cochran, R.C., Owensby, C.E. (2004): Grazing management effects on plant species diversity in tallgrass prairie. - Journal of Range Management 57: 58-65.

[55] Holechek, J. L., Pieper, R.D., Herbel, C.H. (1998): Range management principles and practices. 3rd edition. - Prentice Hall. 542 pp.

[56] Holmes, T.H., Rice, K.J. (1996): Patterns of growth and soil-water utilization in some exotic annuals and native perennial bunchgrasses of California. - Annals of Botany 78 : $233-243$.

[57] Hopkins, H.H. (1954): Effects of mulch upon certain factors of the grassland environment. - Journal of Rangement Management 7: 255-258.

[58] Howland, B., Stojanovic, D., Gordon, I.J., Manning, A.D., Fletcher, D., Lindenmayer, D.B. (2014): Eaten Out of House and Home: Impacts of Grazing on Ground- Dwelling Reptiles in Australian Grasslands and Grassy Woodlands. - PLoS ONE 9: e105966. doi:10.1371/journal.pone.0105966.

[59] Ingerpuu, N., Sarv, M. (2015): Effect of grazing on plant diversity of coastal meadows in Estonia. - Annales Botanici Fennici 52: 84-92.

[60] Jones, A. (2000): Effects of cattle grazing on North America arid ecosystems: a quantitative review. - Western North America Naturalist 60: 155-164.

[61] Jones, W.M., Fraser, L.H., Curtis, P.J. (2010): Plant community functional shifts in response to livestock grazing in intermountain depressional wetlands in British Columbia, Canada. - Biological Conservation 144: 511-517.

[62] Harnett, D.C., Hickman, K.R., Walter, L.E.F. (1996):Effects of bison grazing, fire and topography on floristic diversity in tallgrass prarie. - Journal of Range Management 49: 413-420.

[63] Huston, M. (1979): General hypothesis of species-diversity. - American Naturalist 113: 81-101.

[64] Leinaas, H.P., Bengtsson, J., Janion-Scheepers, C., Chown, S.L. (2015): Indirect effects of habitat disturbance on invasion: nutritious litter from a grazing resistant plant favors alien over native Collembola. - Ecology and Evolution 5: 3462-3471.

[65] Liu, Y., Shi, G., Mao, L., Cheng, G., Jiang, S., Ma, X., An, L., Du, G., Johnson, N.C., Feng, H. (2012): Direct and indirect influences of $8 \mathrm{yr}$ of nitrogen and phosphorus fertilization on Glomeromycota in an alpine meadow ecosystem. - New Phytologist 194: 523-535. doi: 10.1111/j.1469-8137.2012.04050.x.

[66] Maestas, J. D., Knight, R.L., Gilgert, W.C. (2003): Biodiversity across a rural land-use gradient. - Conservation Biology 17: 1425-1434.

[67] Magurran, A.E. (2004): Measuring Biological Diversity. - Blackwell Publishing, Malden, MA. 
[68] Marty, J.T. (2005): Effects of Cattle Grazing on Diversity in Ephemeral Wetlands. Conservation Biology 19: 1626-1632.

[69] Matthew, K. M. (1999): Flora of Palni Hills, India. - Oxford \& IBH Publishing, New Delhi, India.

[70] Mayer, R., Kaufmann, R., Vorhauser, K., Erschbamer, B. (2009): Effects of grazing exclusion on species composition in high-altitude grasslands of the Central Alps. - Basic and Applied Ecology 10: 447-455. DOI 10.1016/j.baae.2008.10.004.

[71] McIntyre, S., Heard, K.M., Martin, T.G. (2003): The relative importance of cattle grazing in subtropical grasslands: does it reduce or enhance plant biodiversity? - Journal of Applied Ecology 40: 445-457.

[72] Metera, E., Sakowski, T., Słoniewski, K., Romanowicz, B. (2010): Grazing as a tool to maintain biodiversity of grassland - a review. - Animal SciencePapers and Reports 28: 315-334.

[73] Milchunas, D. G., Lauenroth, W. K. (1993): Quantitative effects of grazing on vegetation and soils over a global range of environments. - Ecological Monographs 63: 327-366.

[74] Milchunas, D.G., Sala, O.E., Lauenroth, W.K. (1988): A generalized model of the effects of grazing by large herbivores on grassland community structure. - The American Naturalist 132: 87-106.

[75] Milchunas, D.G., Lauenroth, W.K., Chapman, P.L., Kazempour, M.K. (1989): Effects of grazing, topography, and precipitation on the structure of semiarid grassland. - Vegetatio 80: $11-23$.

[76] Mohandass, D. (2008): Floristic Distribution in Montane Swamps of the Nilgiri Mountains, Southern India. - International Journal of Ecology and Environmental Sciences 34: 55-62.

[77] Mohandass, D. (2013): Pollination ecology of Impatiens rufescens (Balsamineae) - An Endemic annual herb from Nilgiri Mountains, Western Ghats, India. - International Journal of Ecology and Environmental Sciences 39: 59-65.

[78] Mohandass, D., Puyravaud, J-P., Hughes, A.C., Davidar, P., Ganesh, P.S., Campbell, M. (2014): Edge transition impacts on swamp plant communities in the Nilgiri Mountains, southern India. - Applied Ecology and Environmental Research 12: 909-929.

[79] Mysterud, A. (2006): The concept of overgrazing and its role in management of large herbivores. - Wildlife Biology 12: 129-141.

[80] Noy-Meir, I. (1995: Interactive effects of fire and grazing on the structure and diversity of Mediterranean grasslands. - Journal of Vegetation Science 6: 701-710.

[81] Olff, H., Ritchie, M.E. (1998): Effects of herbivores on grassland plant diversity. Trends in Ecology and Evolution, 13: 261-265.

[82] Økland R.H., Rydgren, K., Økland, T. (2003): Composition of boreal spruce swamp forests: closed doors and windows of opportunity. - Ecology 84: 1909-1919.

[83] Pandey, C. B., Singh, J. S. (1991): Influence of grazing and soil conditions on derived savanna vegetation in India. Journal of Vegetation Science 2: 95-102.

[84] Papanastasis, V.P. (2009): Restorations of degraded grazing lands through grazing management: can it work? - Restoration Ecology 17: 441-445.

[85] Patón, D., Zaballost, T., Tovar, J. (1995). Ecología del comportamiento del ganado vacuno Retinto en pastoreo. Relaciones entre intensidad de uso, diversidad ecológica y composición botánica del pastizal. - Arch Zootec 44: 303-315.

[86] Perevolotsky, A., Seligman, N. G. (1998): Role of grazing in Mediterranean rangeland ecosystems. - BioScience 48: 1007-1017.

[87] Proulx, M., Mazumder, A. (1998): Reversal of grazing impact on plant species richness in nutrient-poor vs. nutrient-rich ecosystems. - Ecology 79: 2581-2592.

[88] Pueyo, Y., Alados, C.L., Ferrer, C. (2003): Biodiversidad, grado de cobertura y estructura espacial de las comunidades de palmitar del Sureste Ibérico (Parque Natural del Cabo de Gata-Níjar) a lo largo de un gradiente de pastoreo. Proc. XLIII Reunión Científica de la SEEP, Granada,Spain, pp. 701-706. 
[89] Puyravaud, J.-P., Mohandass, D., Chhabra, T. (2003): A rediscovery of Eriochrysis rangacharii Fischer (Poaceae) in the Nilgiri Mountains of southern India. - Candollea 58: 97-100.

[90] Puyravaud, J-P., Mohandass, D., Davidar, P. (2012): Impact of human-related disturbance on Eriochrysis rangacharii Fischer, a rare keystone endemic grass (Nilgiris, southern India): a preliminary assessment. - Tropical Ecology 53: 25-32.

[91] Puyravaud, J.-P., Davidar, P. (2013): The Nilgiris Biosphere Reserve: an unrealized vision for conservation. - Tropical Conservation Science 6: 468-476.

[92] Rangel, T.F., Diniz-Filho, J.A.F. Bini, L.M. (2010): SAM: a comprehensive application for Spatial Analysis in Macroecology. - Ecography 33: 46-50.

[93] Ren, H., Schönbach, P., Wan, H., Gierus, M., Taube, F. (2012): Effects of Grazing Intensity and Environmental Factors on Species Composition and Diversity in Typical Steppe of Inner Mongolia, China. - PLoS ONE 7: e52180. doi:10.1371/journal.pone.0052180.

[94] Rogers, W.E., Hartnett, D.C. (2001): Temporal vegetation dynamics and recolonization mechanisms on different-sized soil disturbances in tall grass prairie. - American Journal of Botany 88: 1634-1642.

[95] Roxburgh, S.H., Shea, K., Wilson, J.B. (2004): The Intermediate Disturbance Hypothesis: Patch Dynamics and Mechanisms of Species Coexistence.- Ecology 85: 359-371.

[96] Sasaki, T., Okayasu, T., Jamsran, U., Takeuchi, K. (2008): Threshold changes in vegetation along a grazing gradient in Mongolian rangelands. - Journal of Ecology 96: $145-154$.

[97] Sasaki, T., Okayasu, T., Ohkuro, T., Shirato, Y., Jamsran, U., Takeuchi, K. (2009): Rainfall variability may modify the effects of long-term exclosure on vegetation in Mandalgobi, Mongolia. - Journal of Arid Environments 73: 949-954.

[98] Schaich, H., Szabó, I., Kaphegyi, T.A.M (2010): Grazing with Galloway cattle for floodplain restoration in the Syr Valley, Luxembourg.- Journal for Nature Conservation 18: 268-277.

[99] Schultz, N.L., Morgan, J.W., Lunt, I.D. (2011): Effects of grazing exclusion on plant species richness and phytomass accumulation vary across a regional productivity gradient.- Journal of Vegetation Science 22: 130-142.

[100] Seabloom, E.W., Harpole, W.S., Reichman, O.J., Tilman, D. (2003): Invasion, competitive dominance, and resource use by exotic and native California grassland species.- Proceedings of the National Academy of Sciences 100: 13384-13389.

[101] Shi, X., Li, X.G., Li, C.T., Zhao, Y., Shang, Z., Ma, Q. (2013): Grazing exclusion decreases soil organic $\mathrm{C}$ storage at an alpine grassland of the Qinghai-Tibetan Plateau. Ecological Engineering 57:183-187. DOI 10.1016/j.ecoleng.2013.04.032

[102] Sigua, G. C., Kang, W.J.,Coleman, S.W. (2006): Soil Profile Distribution of Phosphorus and Other Nutrients following Wetland Conversion to Beef Cattle Pasture.- Journal of Environmental Quality 35: 2374-2382.

[103] Smith, G., Holechek, J.L., Cardenas, M. (1996): Wildlife numbers on excellent and good condition Chihuahuan Desert rangelands: An observation. - Journal of Range Management 49: 489-493.

[104] Taddese, G., Saleem, M.A., Abvie, A., Wagnew, A. (2002): Impact of grazing on plant species richness, plant biomass, plant attribute, and soil physical and hydrological properties of vertisol in East African highlands. - Environmental Management 29: 279289.

[105] Tanner, C.C. (1991): A review of cattle grazing effects on lake margin vegetation with observations from dune lakes in Northland, New Zealand. - New Zealand Natural Sciences 19: 1-14.

[106] Tilman, D., Pacala, S. (1993): The mailltellance of species diversity in plant communities. - In: Ricklefs, R., Schluter, D. (eds) Species Diversity in Ecological Communities, pp. 13-25. University of Chicago Press, Chicago. 
[107] Towne, G., Owensby, C. (1984): Long-term effects of annual burning at different dates in ungrazed Kansas tallgrass prairie. - Journal of Range Management 37: 392-397.

[108] Török, P., Valkóa, O., Deáka, B., Kelemena, A., Tóthb, E., Tóthmérésza, B. (2016): Managing for species composition or diversity? Pastoral and free grazing systems in alkali steppes.- Agriculture, Ecosystems and Environment http://dx.doi.org/10.1016/j.agee.2016.01.010.

[109] Walker, D. A., Alsos, I.G., Bay, C., Lapointe, B.N., Breen, A.L., Bültmann, H., Christensen, T., Damgaard, C., Daniels, F.J.A., Hennekens, S., Raynolds, M.K., Le Roux, P.C., Luoto, M., Pellissier, L., Peet, R.K., Schmidt, N.M.,Stewart, L., Virtanen, R., Yoccoz, N.G., Wisz, M.S. (2013): Rescuing valuable arctic vegetation data for biodiversity models, ecosystem models and a panarctic vegetation classification.- Arctic 66: 133-137.

[110] Waser, N.M., Price, M.V. (1991): Outcrossing distance effects in Delphinium nelsonii. Pollen loads, pollen tubes, and seed set. - Ecology 72: 171-179.

[111] Weaver, J. E., Rowland, N. W. (1952): Effects of Excessive Natural Mulch on Development, Yield, and Structure of Native Grassland. - Agronomy \& Horticulture Faculty Publications, Paper 445.

[112] Wenhong, M. (2007): The relationship between species richness and productivity in four typical grasslands of northern China. - Frontiers of Biology in China 2: 318-323.

[113] Willoughby, M.G., West, N.E. (1996): Species diversity and how it is affected by livestock grazing on Alberta'seastern slopes. - Proc. 4th Int. Rangel. Cong., Salt Lake City,Utah, USA, pp. 610-611.

[114] Wolkovich, M., Bolger, D.T., Holway, D.A. (2009): Complex responses to invasive grass litter by ground arthropods in a Mediterranean scrub ecosystem. - Oecologia 161: 697708. DOI 10.1007/s00442-009-1425-7.

[115] Yan, L., Zhou, G., Zhang, F. (2013): Effects of Different Grazing Intensities on Grassland Production in China: A Meta-Analysis.- Plos One 8: e81466. Doi: 10.1371 journal.pone.0081466.

[116] Yan, Y., Lu, X. (2015): Is grazing exclusion effective in restoring vegetation in degraded alpine grasslands in Tibet, China? - PeerJ 3: e1020, doi:10.7717/peerj.1020.

[117] Yañez-Arenas, C., Guevara, R., Martínez-Meyer, E., Mandujano, S., Lobo, J.M. (2014): Predicting species' abundances from occurrence data: Effects of sample size and bias. Ecological Modelling 294:36-41.

[118] Yuan, Z.Y., Jiao, F., Li, Y.H., Kallenbach, R.L. (2016): Anthropogenic disturbances are key to maintaining the biodiversity of grasslands. - Scientific Reports 6: 22132. Doi: $10.1038 /$ srep22132. 


\section{APPENDIX}

Appendix 1. Complete list of surveyed species, including species names, family, habit, geographic range, life-form, and habitat of each species that were recorded from six swamps in the Upper Nilgiri Mountains, southern India.

\begin{tabular}{|c|c|c|c|c|c|}
\hline Species & Family & Habit & $\begin{array}{l}\text { Geographic } \\
\text { range }\end{array}$ & Life-forms & Habitat \\
\hline $\begin{array}{l}\text { Ageratina adenophora (Spreng.) R.M.King } \\
\text { \& H.Rob. }\end{array}$ & Compositae & Forb & Wide & Annual & Forest/grassland \\
\hline Anaphalis brevifolia DC. & Compositae & Forb & Narrow & Annual forb & Swamps \\
\hline Andropogon lividus Thwaites & Poaceae & Graminoids & Narrow & Perennial grass & Grassland \\
\hline Andropogon polyptychos Steud & Poaceae & Graminoids & Narrow & Perennial grass & Swamps \\
\hline Anemone rivularis Buch.-Ham. ex DC. & Ranunculaceae & Forb & Narrow & Annual forb & Grassland \\
\hline Athyrium hohenackerianum T. Moore & Athyriaceae & Forb & Wide & Perennial forb & Forest/grassla \\
\hline Bolboschoenus maritimus (L.) Palla & Cyperaceae & Graminoids & Narrow & Perennial forb & Swamps \\
\hline Bupleurum distichophyllum Wight \& Arn. & Apiaceae & Forbs & Narrow & Annual forb & Swamps \\
\hline Carex capillacea Boott & Cyperaceae & Graminoids & Narrow & Perennial grass & Swamps \\
\hline Carex lindleyana Nees & Cyperaceae & Graminoids & Narrow & Perennial grass & Grassland/swamps \\
\hline $\begin{array}{l}\text { Carex nubigena D.Don ex Tilloch \& } \\
\text { Taylor }\end{array}$ & Cyperaceae & Graminoids & Narrow & Perennial grass & Grassland/swamps \\
\hline Carex phacota Spreng & Cyperaceae & Grami & Narr & Perennial & Grassland/sw \\
\hline Centella asiatica (L.) Urb. & Apiaceae & Forbs & Wide & Perennial forb & Forest/grassland \\
\hline $\begin{array}{l}\text { Chrysopogon nodulibarbis (Hochst. ex } \\
\text { Steud.) Henrard }\end{array}$ & Poaceae & Graminoids & Narrow & Perennial grass & Grassland \\
\hline Cirsium abukumense Kadota & Compositae & Forb & Narrow & Annual forb & Forest/grassland \\
\hline $\begin{array}{l}\text { Coelachne perpusilla (Nees ex Steud.) } \\
\text { Thwaites }\end{array}$ & Poaceae & Graminoids & Narrow & Perennial grass & Swamps \\
\hline Commelina clavata C.B.Clarke & Commelinaceae & Forb & Wide & Annual forb & Grassland \\
\hline Conyza bonariensis $(\mathrm{L})$. & Compositae & Forb & Wide & Annual forb & Grassland \\
\hline Cyanotis obtusa (Trimen) Trimen & Commelinaceae & Forb & Wide & Perennial grass & Grassland \\
\hline Cyrtococcum deccanense Bor & Poaceae & Graminoids & Narrow & Annual grass & Swamps \\
\hline Dichrocephala chrysanthemifolia (Blume) & Compositae & Forb & Narrow & Annual forb & Grassland \\
\hline
\end{tabular}

APPLIED ECOLOGY AND ENVIRONMENTAL RESEARCH 14(4): 233-268.

http://www.aloki.hu • ISSN 15891623 (Print) • ISSN 17850037 (Online)

DOI: http://dx.doi.org/10.15666/aeer/1404_233268

๑ 2016, ALÖKI Kft., Budapest, Hungary 


\begin{tabular}{|c|c|c|c|c|c|}
\hline$\overline{\mathrm{DC}}$ & & & & & \\
\hline Digitaria stricta Roth & Poaceae & Graminoids & Narrow & Annual forb & Grassland/swamps \\
\hline Drosera burmanni Vahl & Lentibularaceae & Forb & Wide & Annual forb & Grassland/swamps \\
\hline Drosera peltata Thunb. & Lentibularaceae & Forb & Narrow & Annual forb & Grassland \\
\hline Eleocharis congesta D.Don & Cyperaceae & Graminoids & Narrow & Perennial forb & Swamps \\
\hline Erigeron karvinskianus DC & Compositae & Forb & Wide & Perennial forb & Grassland \\
\hline Eriocaulon brownianum Mart. & Eriocaulaceae & Forb & Narrow & Perennial grass & Swamps \\
\hline Eriocaulon odoratum Dalzell. & Eriocaulaceae & Forb & Narrow & Perennial forb & Swamps \\
\hline Eriocaulon robustum Steud. & Eriocaulaceae & Forb & Narrow & Perennial forb & Swamps \\
\hline Eriochrysis rangacharii C.E.C.Fisch. & Poaceae & Graminoids & Narrow & Perennial forb & Swamps \\
\hline Eulalia phaeothrix (Hack.) Kuntze & Poaceae & Graminoids & Wide & Perennial forb & Swamps \\
\hline Fimbristylis quinquangularis (Vahl) Kunth & Cyperaceae & Graminoids & Narrow & Annual forb & Swamps \\
\hline Fragaria nilgerrensis Schltdl. ex J.Gay & Rosaceae & Forb & Narrow & Annual forb & Forest/grassland \\
\hline Fragaria vesca $\mathrm{L}$. & Rosaceae & Forb & Wide & Annual forb & Forest/grassland \\
\hline Gaultheria fragrantissima Wall. & Ericaceae & Tree & Narrow & Perennial tree & Forest/grassland \\
\hline Gentiana pedicillata var. wightii & Gentianaceae & Forb & Narrow & Perennial forb & Forest/grassland \\
\hline Gentiana quadrifaria Blume & Gentianaceae & Forb & Narrow & Annual forb & Forest/grassland \\
\hline Geranium nepalense Sweet & Geraniaceae & Forb & Narrow & Annual forb & Grassland \\
\hline Hydrocotyle sibthorpioides Lam. & Araliaceae & Forbs & Narrow & Annual forb & Forest/grassland \\
\hline Hypochoeris argentina Cabrera & Compositae & Forb & Narrow & Annual forb & Grassland/swamps \\
\hline Impatiens chinensis L. & Balsaminaceae & Forb & Wide & Annual forb & Grassland \\
\hline Impatiens rufescens Benth. & Balsaminaceae & Forb & Narrow & Annual forb & Swamps \\
\hline $\begin{array}{l}\text { Isachne kunthiana (Wight \& Arn. ex } \\
\text { Steud.) Miq. }\end{array}$ & Poaceae & Graminoids & Narrow & Perennial grass & Grassland/swamps \\
\hline Ischaemum commutatum Hack. & Poaceae & Graminoids & Narrow & Perennial grass & Grassland/swamps \\
\hline Juncus effusus L. & Juncaceae & Graminoids & Narrow & Perennial grass & Swamps \\
\hline Juncus inflexus L. & Juncaceae & Graminoids & Narrow & Perennial grass & Swamps \\
\hline Juncus prismatocarpus $\mathrm{R} . \mathrm{Br}$. & Juncaceae & Graminoids & Wide & Perennial grass & Swamps \\
\hline Kyllinga melanosperma Nees & Cyperaceae & Graminoids & Narrow & Perennial grass & Grassland/swamps \\
\hline Laurembergia coccinea Kanitz & Haloragaceae & Forb & Narrow & Perennial forb & Swamps \\
\hline Leucas marrubioides Desf. & Lamiaceae & Forb & Narrow & Perennial forb & Grassland/swamps \\
\hline Lipocarpha chinensis (Osbeck) J.Kern & Cyperaceae & Graminoids & Narrow & Perennial grass & Swamps \\
\hline
\end{tabular}

APPLIED ECOLOGY AND ENVIRONMENTAL RESEARCH 14(4): 233-268.

http://www.aloki.hu • ISSN 15891623 (Print) • ISSN 17850037 (Online)

DOI: http://dx.doi.org/10.15666/aeer/1404_233268

๑ 2016, ALÖKI Kft., Budapest, Hungary 


\begin{tabular}{|c|c|c|c|c|c|}
\hline Neanotis indica (DC.) W.H.Lewis & Rubiaceae & Forb & Narrow & Perennial forb & Swamps \\
\hline Ophelia corymbosa Griseb & Gentianaceae & Forb & Narrow & Annual & Grassland \\
\hline Osbeckia brachystemon Naudin & Melastomataceae & Forb & Narrow & Annual forb & Swamps \\
\hline Oxalis corniculata $\mathrm{L}$. & Oxalidaceae & Forb & Wide & Annual forb & Grassland \\
\hline $\begin{array}{l}\text { Parnassia mysorensis F. Heyne ex Wight } \\
\& \text { Arn }\end{array}$ & Celastraceae & Forb & Narrow & Annual forb & Grassland/swamps \\
\hline Persicaria nepalensis (Meisn.) Miyabe & Polyagonaceae & Forb & Narrow & Perennial & Grassland \\
\hline Pinus patula Schiede ex Schltdl. \& Cham. & Pinaceae & Tree & Narrow & Perennial forb & Grassland \\
\hline $\begin{array}{l}\text { Plantago asiatica subsp. erosa (Wall.) } \\
\text { Z.Yu Li }\end{array}$ & Plantaginaceae & Tree & Narrow & Perennial forb & Forest/grassland \\
\hline $\begin{array}{l}\text { Pleiocraterium verticillare (Wall. ex Wight } \\
\text { \& Am.) Bremek. }\end{array}$ & Rubiaceae & Forb & Narrow & Perennial forb & Swamps \\
\hline Polytrias indica (Houtt.) Veldkamp & Poaceae & Forb & Wide & Perennial grass & Grassland/swamps \\
\hline Potentilla leschenaultiana Ser. & Rosaceae & Forb & Narrow & Perennial forb & Forest/grassland \\
\hline Pteridium aquilinum (L.) Kuhn & Denstaedtiaceae & Forb & Wide & Annual forb & Forest/grassland \\
\hline Pycreus flavidus (Retz.) T.Koyama & Cyperaceae & Graminoids & Narrow & Perennial grass & Grassland/swamps \\
\hline Ranunculus diffusus DC. & Rosaceae & Graminoids & Narrow & Perennial forb & Swamps \\
\hline $\begin{array}{l}\text { Ranunculus reniformis Wall. ex Wight \& } \\
\text { Arn. }\end{array}$ & Ranunculaceae & Forb & Narrow & Perennial forb & Swamps \\
\hline Rhynchospora rugosa (Vahl) Gale & Cyperaceae & Graminoids & Narrow & Perennial & Swamps \\
\hline Rotala fysonii Blatt. \& Hallb. & Lythraceae & Graminoids & Narrow & Annual forb & Grassland \\
\hline Rubus racemosus Genev. & Rosaceae & Forb & Narrow & Perennial vine & Forest/grassland \\
\hline Satyrium nepalense D.Don & Orchidaceae & Vine & Narrow & Annual forb & Grassland \\
\hline $\begin{array}{l}\text { Schoenoplectiella mucronata (L.) J.Jung \& } \\
\text { H.K. Choi }\end{array}$ & Cyperaceae & Graminoids & Narrow & Perennial grass & Swamps \\
\hline $\begin{array}{l}\text { Senecio wightii (DC. ex Wight) Benth. Ex } \\
\text { C.B. Clarke }\end{array}$ & Compositae & Graminoids & Narrow & Annual forb & Swamps \\
\hline Themeda tremula (Nees ex Steud.) Hack. & Poaceae & Forbs & Narrow & Perennial grass & Grassland/swamps \\
\hline Utricularia graminifolia Vahl & Lentibularaceae & Graminoids & Narrow & Annual forb & Grassland \\
\hline Utricularia scandens Benj. & Lentibularaceae & Forb & Narrow & Annual forb & Grassland \\
\hline Viola pilosa Blume & Violaceae & Forb & Narrow & Perennial forb & Forest/grassland \\
\hline Wahlenbergia marginata (Thunb.) A.DC. & Campanulaceae & Forb & Narrow & Perennial forb & Forest/grassland \\
\hline Xyris capensis Thunb. & Xyridaceae & Forb & Narrow & Annual forb & Swamps \\
\hline
\end{tabular}


Appendix 2. List of frequency of each species distributed in each swamp based on abundance through quantitative assessment among different grazing disturbance and sampling that were recorded from six swamps in the Korakundah and Upper Bhavani Reserve Forest, Nilgiri Mountains, southern India.

\begin{tabular}{|c|c|c|c|c|c|c|c|c|c|c|c|c|}
\hline Species & Family & $\begin{array}{l}\text { High- } \\
\text { grazing }\end{array}$ & $\begin{array}{l}\text { Low- } \\
\text { grazing }\end{array}$ & $\begin{array}{l}\text { Moderat } \\
\text { e- } \\
\text { grazing }\end{array}$ & $\begin{array}{l}\text { Gran } \\
\mathrm{d} \\
\text { Total }\end{array}$ & GD & QT & $\mathrm{KV}$ & $\mathrm{TE}$ & OT & $\mathrm{PC}$ & $\begin{array}{l}\text { Grand } \\
\text { Total }\end{array}$ \\
\hline $\begin{array}{l}\text { Ageratina adenophora } \\
\text { (Spreng.) R.M.King \& } \\
\text { H.Rob. }\end{array}$ & Compositae & 3 & 0 & 3 & 6 & 3 & 0 & 0 & 0 & 0 & 3 & 6 \\
\hline Anaphalis brevifolia DC. & Compositae & 17 & 27 & 14 & 58 & 12 & 5 & 11 & 1 & 14 & 0 & 58 \\
\hline $\begin{array}{l}\text { Andropogon lividus } \\
\text { Thwaites }\end{array}$ & Poaceae & 8 & 10 & 9 & 27 & 0 & 8 & 6 & 4 & 9 & 0 & 27 \\
\hline $\begin{array}{l}\text { Andropogon polyptychos } \\
\text { Steud }\end{array}$ & Poaceae & 155 & 190 & 196 & 541 & 100 & 55 & 74 & 116 & 48 & 148 & 541 \\
\hline $\begin{array}{l}\text { Anemone rivularis Buch.- } \\
\text { Ham. ex DC. }\end{array}$ & Ranunculaceae & 0 & 0 & 2 & 2 & 0 & 0 & 0 & 0 & 2 & 0 & 2 \\
\hline $\begin{array}{l}\text { Athyrium } \\
\text { hohenackerianum } \mathrm{T} \text {. } \\
\text { Moore }\end{array}$ & Athyriaceae & 2 & 0 & 1 & 3 & 2 & 0 & 0 & 0 & 0 & 1 & 3 \\
\hline $\begin{array}{l}\text { Bolboschoenus maritimus } \\
\text { (L.) Palla }\end{array}$ & Cyperaceae & 3 & 0 & 2 & 5 & 2 & 1 & 0 & 0 & 0 & 2 & 5 \\
\hline $\begin{array}{l}\text { Bupleurum } \\
\text { distichophyllum Wight \& } \\
\text { Arn. }\end{array}$ & Apiaceae & 0 & 0 & 2 & 2 & 0 & 0 & 0 & 0 & 0 & 2 & 2 \\
\hline Carex capillacea Boott & Cyperaceae & 6 & 0 & 80 & 86 & 6 & 0 & 0 & 0 & 0 & 80 & 86 \\
\hline Carex lindleyana Nees & Cyperaceae & 21 & 55 & 64 & 140 & 9 & 12 & 40 & 1 & 60 & 4 & 14 \\
\hline $\begin{array}{l}\text { Carex nubigena D.Don ex } \\
\text { Tilloch \& Taylor }\end{array}$ & Cyperaceae & 8 & 0 & 11 & 19 & 0 & 8 & 0 & 0 & 8 & 3 & 19 \\
\hline Carex phacota Spreng & Cyperaceae & 5 & 0 & 8 & 13 & 0 & 5 & 0 & 0 & 8 & 0 & 13 \\
\hline $\begin{array}{l}\text { Centella asiatica (L.) } \\
\text { Urb. }\end{array}$ & Apiaceae & 1 & 2 & 0 & 3 & 0 & 1 & 2 & 0 & 0 & 0 & 3 \\
\hline $\begin{array}{l}\text { Chrysopogon } \\
\text { nodulibarbis (Hochst. ex } \\
\text { Steud.) Henrard } \\
\end{array}$ & Poaceae & 12 & 24 & 1 & 37 & 12 & 0 & 11 & 13 & 0 & 1 & 37 \\
\hline
\end{tabular}

APPLIED ECOLOGY AND ENVIRONMENTAL RESEARCH 14(4): 233-268 http://www.aloki.hu • ISSN 15891623 (Print) • ISSN 17850037 (Online)

DOI: http://dx.doi.org/10.15666/aeer/1404_233268

(c) 2016, ALÖKI Kft., Budapest, Hungary 


\begin{tabular}{|c|c|c|c|c|c|c|c|c|c|c|c|c|}
\hline $\begin{array}{l}\text { Cirsium abukumense } \\
\text { Kadota }\end{array}$ & Compositae & 0 & 0 & 4 & 4 & 0 & 0 & 0 & 0 & 4 & 0 & 4 \\
\hline $\begin{array}{l}\text { Coelachne perpusilla } \\
\text { (Nees ex Steud.) Thwaites }\end{array}$ & Poaceae & 2 & 3 & 4 & 9 & 0 & 2 & 3 & 0 & 0 & 4 & 9 \\
\hline $\begin{array}{l}\text { Commelina clavata } \\
\text { C.B.Clarke }\end{array}$ & Commelinaceae & 6 & 0 & 3 & 9 & 0 & 6 & 0 & 0 & 3 & 0 & 9 \\
\hline Conyza bonariensis $(\mathrm{L})$. & Compositae & 0 & 1 & 0 & 1 & 0 & 0 & 0 & 1 & 0 & 0 & 1 \\
\hline $\begin{array}{l}\text { Cyanotis obtusa (Trimen) } \\
\text { Trimen }\end{array}$ & Commelinaceae & 0 & 0 & 6 & 6 & 0 & 0 & 0 & 0 & 0 & 6 & 6 \\
\hline $\begin{array}{l}\text { Cyrtococcum deccanense } \\
\text { Bor }\end{array}$ & Poaceae & 107 & 77 & 56 & 240 & 13 & 94 & 62 & 15 & 34 & 22 & 240 \\
\hline $\begin{array}{l}\text { Dichrocephala } \\
\text { chrysanthemifolia } \\
\text { (Blume) DC }\end{array}$ & Compositae & 2 & 0 & 4 & 6 & 2 & 0 & 0 & 0 & 0 & 4 & 6 \\
\hline Digitaria stricta Roth & Poaceae & 9 & 16 & 12 & 37 & 0 & 9 & 12 & 4 & 4 & 8 & 37 \\
\hline Drosera burmanni Vahl & Lentibularaceae & 8 & 0 & 6 & 14 & 3 & 5 & 0 & 0 & 0 & 6 & 14 \\
\hline Drosera peltata Thunb. & Lentibularaceae & 1 & 0 & 3 & 4 & 1 & 0 & 0 & 0 & 1 & 2 & 4 \\
\hline $\begin{array}{l}\text { Eleocharis congesta } \\
\text { D.Don }\end{array}$ & Cyperaceae & 0 & 5 & 7 & 12 & 0 & 0 & 0 & 5 & 7 & 0 & 12 \\
\hline $\begin{array}{l}\text { Erigeron karvinskianus } \\
\text { DC }\end{array}$ & Compositae & 0 & 4 & 2 & 6 & 0 & 0 & 4 & 0 & 0 & 2 & 6 \\
\hline $\begin{array}{l}\text { Eriocaulon brownianum } \\
\text { Mart. }\end{array}$ & Eriocaulaceae & 74 & 73 & 123 & 270 & 38 & 36 & 8 & 65 & 47 & 76 & 270 \\
\hline $\begin{array}{l}\text { Eriocaulon odoratum } \\
\text { Dalzell. }\end{array}$ & Eriocaulaceae & 0 & 8 & 13 & 21 & 0 & 0 & 8 & 0 & 13 & 0 & 21 \\
\hline $\begin{array}{l}\text { Eriocaulon robustum } \\
\text { Steud. }\end{array}$ & Eriocaulaceae & 5 & 8 & 0 & 13 & 5 & 0 & 4 & 4 & 0 & 0 & 13 \\
\hline $\begin{array}{l}\text { Eriochrysis rangacharii } \\
\text { C.E.C.Fisch. }\end{array}$ & Poaceae & 83 & 152 & 113 & 348 & 57 & 0 & 72 & 80 & 31 & 82 & 348 \\
\hline $\begin{array}{l}\text { Eulalia phaeothrix } \\
\text { (Hack.) Kuntze }\end{array}$ & Poaceae & 3 & 0 & 2 & 5 & 0 & 3 & 0 & 0 & 2 & 0 & 5 \\
\hline $\begin{array}{l}\text { Fimbristylis } \\
\text { quinquangularis (Vahl) } \\
\text { Kunth }\end{array}$ & Cyperaceae & 0 & 2 & 15 & 17 & 0 & 0 & 0 & 0 & 17 & 0 & 17 \\
\hline Fragaria nilgerrensis & Rosaceae & 50 & 52 & 6 & 108 & 29 & 21 & 19 & 3 & 6 & 0 & 108 \\
\hline
\end{tabular}




\begin{tabular}{|c|c|c|c|c|c|c|c|c|c|c|c|c|}
\hline Schltdl. ex J.Gay & & & & & & & & & & & & \\
\hline Fragaria vesca L. & Rosaceae & 0 & 2 & 0 & 2 & 0 & 0 & 2 & 0 & 0 & 0 & 2 \\
\hline $\begin{array}{l}\text { Gaultheria fragrantissima } \\
\text { Wall. }\end{array}$ & Ericaceae & 0 & 2 & 0 & 2 & 0 & 0 & 0 & 2 & 0 & 0 & 2 \\
\hline $\begin{array}{l}\text { Gentiana pedicillata var. } \\
\text { wightii }\end{array}$ & Gentianaceae & 9 & 14 & 13 & 36 & 0 & 9 & 7 & 7 & 6 & 7 & 36 \\
\hline $\begin{array}{l}\text { Gentiana quadrifaria } \\
\text { Blume }\end{array}$ & Gentianaceae & 4 & 0 & 7 & 11 & 0 & 4 & 0 & 0 & 7 & 0 & 11 \\
\hline $\begin{array}{l}\text { Geranium nepalense } \\
\text { Sweet }\end{array}$ & Geraniaceae & 0 & 9 & 3 & 12 & 0 & 0 & 5 & 4 & 0 & 3 & 12 \\
\hline $\begin{array}{l}\text { Hydrocotyle } \\
\text { sibthorpioides Lam. }\end{array}$ & Araliaceae & 5 & 8 & 10 & 23 & 0 & 5 & 8 & 0 & 10 & 0 & 23 \\
\hline $\begin{array}{l}\text { Hypochoeris argentina } \\
\text { Cabrera }\end{array}$ & Compositae & 5 & 17 & 11 & 33 & 0 & 5 & 17 & 0 & 7 & 4 & 33 \\
\hline Impatiens chinensis L. & Balsaminaceae & 2 & 0 & 0 & 2 & 0 & 2 & 0 & 0 & 0 & 0 & 2 \\
\hline $\begin{array}{l}\text { Impatiens rufescens } \\
\text { Benth. }\end{array}$ & Balsaminaceae & 0 & 43 & 0 & 43 & 0 & 0 & 43 & 0 & 0 & 0 & 43 \\
\hline $\begin{array}{l}\text { Isachne kunthiana (Wight } \\
\text { \& Arn. ex Steud.) Miq. }\end{array}$ & Poaceae & 7 & 24 & 1 & 32 & 7 & 0 & 17 & 7 & 0 & 1 & 32 \\
\hline $\begin{array}{l}\text { Ischaemum commutatum } \\
\text { Hack. }\end{array}$ & Poaceae & 61 & 14 & 18 & 93 & 0 & 61 & 0 & 14 & 18 & 0 & 93 \\
\hline Juncus effusus L. & Juncaceae & 109 & 135 & 68 & 312 & 74 & 35 & 55 & 80 & 41 & 27 & 312 \\
\hline Juncus inflexus L. & Juncaceae & 0 & 2 & 1 & 3 & 0 & 0 & 1 & 0 & 1 & 1 & 3 \\
\hline $\begin{array}{l}\text { Juncus prismatocarpus } \\
\text { R.Br. }\end{array}$ & Juncaceae & 9 & 7 & 34 & 50 & 6 & 3 & 0 & 7 & 21 & 13 & 50 \\
\hline $\begin{array}{l}\text { Kyllinga melanosperma } \\
\text { Nees }\end{array}$ & Cyperaceae & 0 & 20 & 0 & 20 & 0 & 0 & 20 & 0 & 0 & 0 & 20 \\
\hline $\begin{array}{l}\text { Laurembergia coccinea } \\
\text { Kanitz }\end{array}$ & Haloragaceae & 3 & 3 & 16 & 22 & 0 & 3 & 3 & 0 & 8 & 8 & 22 \\
\hline $\begin{array}{l}\text { Leucas marrubioides } \\
\text { Desf. }\end{array}$ & Lamiaceae & 0 & 10 & 6 & 16 & 0 & 0 & 10 & 0 & 0 & 6 & 16 \\
\hline $\begin{array}{l}\text { Lipocarpha chinensis } \\
\text { (Osbeck) J.Kern }\end{array}$ & Cyperaceae & 5 & 0 & 7 & 12 & 0 & 5 & 0 & 0 & 7 & 0 & 12 \\
\hline $\begin{array}{l}\text { Neanotis indica (DC.) } \\
\text { W.H.Lewis }\end{array}$ & Rubiaceae & 9 & 52 & 29 & 90 & 9 & 0 & 40 & 12 & 0 & 29 & 90 \\
\hline
\end{tabular}




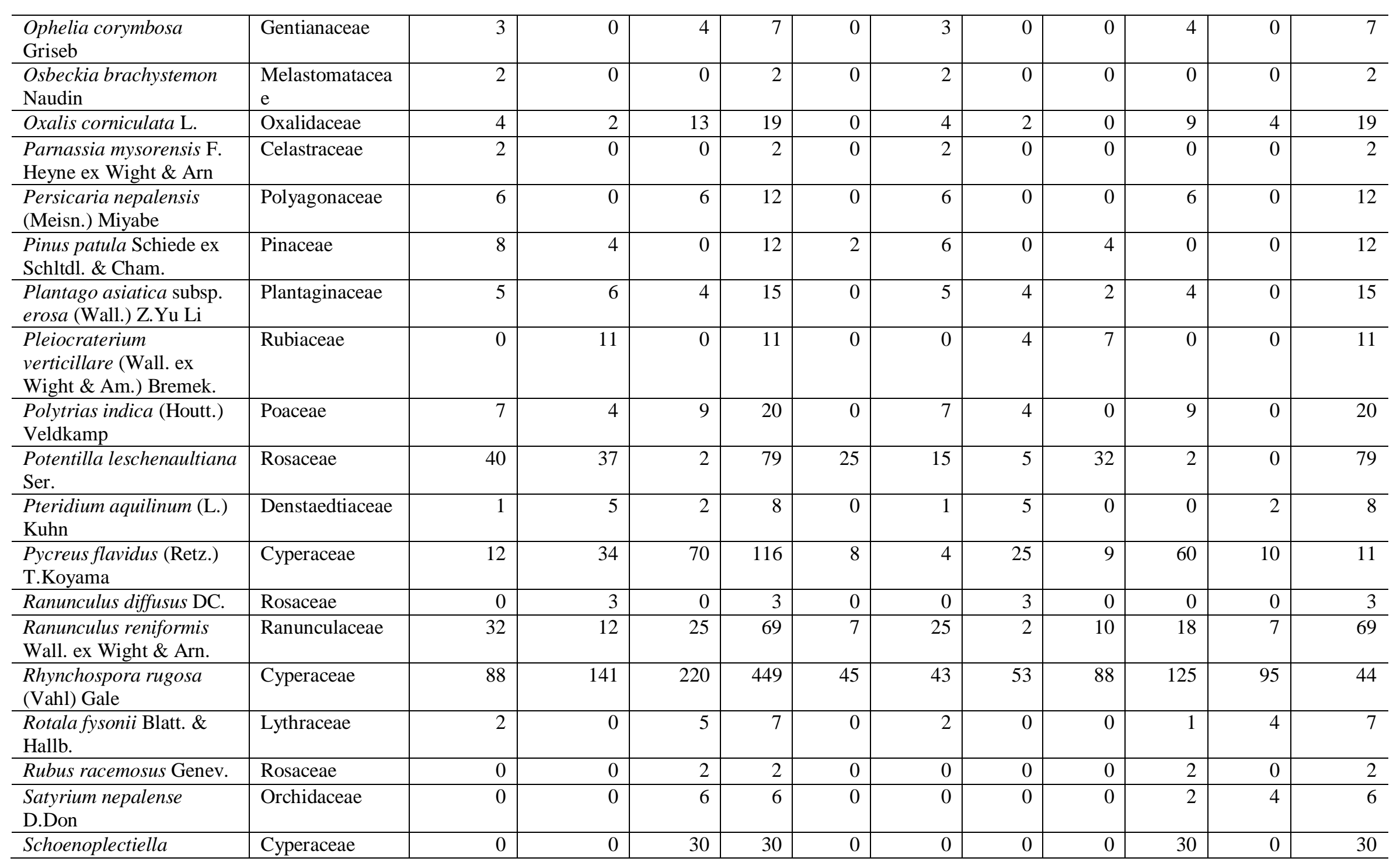




\begin{tabular}{|c|c|c|c|c|c|c|c|c|c|c|c|c|}
\hline $\begin{array}{l}\text { mucronata (L.) J.Jung \& } \\
\text { H.K. Choi }\end{array}$ & & & & & & & & & & & & \\
\hline $\begin{array}{l}\text { Senecio wightii (DC. ex } \\
\text { Wight) Benth. Ex C.B. } \\
\text { Clarke }\end{array}$ & Compositae & 5 & 7 & 4 & 16 & 3 & 2 & 4 & 3 & 0 & 4 & 16 \\
\hline $\begin{array}{l}\text { Themeda tremula (Nees } \\
\text { ex Steud.) Hack. }\end{array}$ & Poaceae & 0 & 0 & 4 & 4 & 0 & 0 & 0 & 0 & 0 & 4 & 4 \\
\hline $\begin{array}{l}\text { Utricularia graminifolia } \\
\text { Vahl }\end{array}$ & Lentibularaceae & 2 & 0 & 0 & 2 & 0 & 2 & 0 & 0 & 0 & 0 & 2 \\
\hline $\begin{array}{l}\text { Utricularia scandens } \\
\text { Benj. }\end{array}$ & Lentibularaceae & 3 & 0 & 0 & 3 & 3 & 0 & 0 & 0 & 0 & 0 & 3 \\
\hline Viola pilosa Blume & Violaceae & 0 & 5 & 9 & 14 & 0 & 0 & 5 & 0 & 0 & 9 & 14 \\
\hline $\begin{array}{l}\text { Wahlenbergia marginata } \\
\text { (Thunb.) A.DC. }\end{array}$ & Campanulaceae & 0 & 0 & 2 & 2 & 0 & 0 & 0 & 0 & 0 & 2 & 2 \\
\hline Xyris capensis Thunb. & Xyridaceae & 0 & 2 & 21 & 23 & 0 & 0 & 2 & 0 & 11 & 10 & 23 \\
\hline Grand total & & 1041 & 1344 & 1434 & 3819 & 483 & 532 & 682 & 659 & 727 & 710 & 3819 \\
\hline
\end{tabular}

